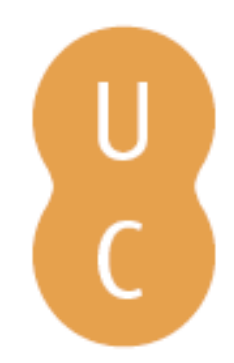

\title{
pompalina
}

\section{Os humanistas e o poder: direito e cência política no contexto do renascimento}

Autor(es): $\quad$ Soares, Nair de Nazaré Castro

Publicado por: Imprensa da Universidade de Coimbra; Annablume

URL

persistente: URI:http://hdl.handle.net/10316.2/40849

DOI: $\quad$ DOI:https://doi.org/10.14195/978-989-26-1280-5_22

Accessed : $\quad$ 26-Apr-2023 13:26:34

A navegação consulta e descarregamento dos títulos inseridos nas Bibliotecas Digitais UC Digitalis, UC Pombalina e UC Impactum, pressupõem a aceitação plena e sem reservas dos Termos e Condições de Uso destas Bibliotecas Digitais, disponíveis em https://digitalis.uc.pt/pt-pt/termos.

Conforme exposto nos referidos Termos e Condições de Uso, o descarregamento de títulos de acesso restrito requer uma licença válida de autorização devendo o utilizador aceder ao(s) documento(s) a partir de um endereço de IP da instituição detentora da supramencionada licença.

Ao utilizador é apenas permitido o descarregamento para uso pessoal, pelo que o emprego do(s) título(s) descarregado(s) para outro fim, designadamente comercial, carece de autorização do respetivo autor ou editor da obra.

Na medida em que todas as obras da UC Digitalis se encontram protegidas pelo Código do Direito de Autor e Direitos Conexos e demais legislação aplicável, toda a cópia, parcial ou total, deste documento, nos casos em que é legalmente admitida, deverá conter ou fazer-se acompanhar por este aviso.

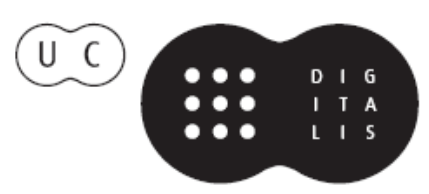




\section{Pólis/Cosmópolis}

\section{Identidades Globais \& Locais}

Carmen Soares, Maria do Céu Fialho \& Thomas Figueira (coords.)

IMPRENSA DA UNIVERSIDADE DE COIMBRA 


\title{
Os Humanistas e o poder. Direito e Cência Política no Contexto do Renascimento (Humanists and Power. Law and Political Science in the Context of the Renaissance)
}

\author{
Nair de Nazaré Castro Soares (ncastrosoares@gmail.com) \\ Universidade de Coimbra \\ Homenagem a meu saudoso Irmão \\ Hélio Mário de Castro Pereira \\ Jurista ilustre e "Advogado dos pobres". \\ Exemplo de Sabedoria e Generosidade*
}

\begin{abstract}
Resumo - O interesse que o direito romano suscitava na Europa, de que foram intérpretes os primeiros humanistas - praticamente todos foram juristas - foi um dos aspectos essenciais na evolução do processo histórico. Desde o tempo de D. João II, a cultura jurídica de formação italiana conhece grande prestígio. Cataldo Parísio Sículo, considerado o introdutor do Humanismo em Portugal, é Doutor em Direito pela Universidade de Ferrara e mestre na de Bolonha. D. João III regulamenta, em termos modernos, o ensino das Leis na sua Academia e ordena a leitura de $\mathrm{S}$. Tomás na primeira cátedra de Teologia, regida por Martin de Ledesma, um dos discípulos mais famosos de Francisco Vitória, na conhecida Escola Jurídica de Salamanca. Apesar do romanismo nascente e da publicação de Il principe de Maquiavel, o modelo do príncipe, elaborado de acordo com o idealismo político-social e religioso, imbuído de neoplatonismo, divulgado por Erasmo, impôs-se na literatura europeia, e de forma particular na Península Ibérica. No contexto do Renascimento, as relações dos humanistas com o poder, assentes na ciência política e no direito - ancorados na mensagem da Antiguidade clássica, assimilada aos valores do Cristianismo - reflectem uma nova dimensão do humano, presente na ideologia e na doutrina que caracterizam a literatura do século de ouro português e europeu.

Palavras-chave: Humanismo do Renascimento; ciência jurídica; pedagogia política; o modelo do príncipe "umanizzato"; literatura e parénese; os humanistas e sua relação com o poder.
\end{abstract}

Авstract: The interest of Renaissance Europe in Roman law exemplifies one of the main aspects of European historical evolution. The early humanists were nearly all

Hélio Mário de Castro Pereira (Alvarenga, 18 de Maio de 1947 -Portalegre, 19 de Abril de 2015) distinguiu-se, desde muito cedo, pela grandeza de carácter, inteligência, natural bondade e desprendimento. Serviu, como Alferes Miliciano, "Oficial de transmissões”, na Guerra Colonial, em Moçambique, sob a divisa horaciana (Ode 3. 2.13), Dulce et decorum est pro patria mori. O seu saber jurídico, adquirido na Alma Mater Conimbrigensis, e um inexcedível sentido dos outros deram brilho à sua abnegada vida de advogado. Autor da famosa "Sentença de Portalegre", defendia empenhada e graciosamente os mais desfavorecidos, tendo merecido ser homenageado, na Assembleia da República, a 24 de Abril de 2015, como "O Advogado dos Pobres". 
jurists who applied themselves to the interpretation of Roman law. From the time of King João (John) II, legal culture under Italian inspiration had attained great prestige. Cataldo Parísio Sículo, who is considered the introducer of humanism into Portugal, had been made a Doctor in Jurisprudence by the University of Ferrara and had been a Master at the University of Bologna. King João III regulated, in modern terms, the teaching of law in his Academy and orders lecturing on Thomas Aquinas for the first chair of Theology, held by Martin de Ledesma, one of the most famous students of Francisco de Victoria at the renowned School of Law at Salamanca. Despite the success of Machiavelli's Il Principe, the ideal of the 'prince', conceived in accordance with sociopolitical and religious idealism, and deeply influenced by a Neoplatonism disseminated by Erasmus, impressed itself on European literature and, particularly, on Iberian literature. In the context of the Renaissance, the relations of Humanists with state power, based on a conception of jurisprudence - one anchored in the heritage of Classical Antiquity as assimilated to the values of Christianity - reflect a new dimension of human values present in the ideology and learning that characterize Portuguese and European literature of the Golden Century.

Key words: Renaissance Humanism, jurisprudence, political pedagogy, humanist prince ideology, literature and paraenesis, humanists and state power.

O ideal de perfeição humana, ligado ao conceito da formação integral da personalidade, vai ser a tónica do Humanismo Renascentista, cívico e pedagógico, herdeiro do ideal de aretê politikê e de paideia, transmitido sobretudo pelos autores gregos do século IV a. C.

Já Isócrates definira os princípios éticos que deveriam orientar a conduta do governante, factor único da sua missão, num tratado $A$ Nicocles, que pode considerar-se o primeiro deste género literário e é apontado por Erasmo como fonte da sua Institutio principis christiani, modelo privilegiado no quinhentismo europeu.

A literatura da época helenística e os sistemas filosóficos então em vigor fomentaram a perspectiva moralizante da problemática política. A interdependência ou aliança da moral e da política vigora também no período imperial romano e consolida-se sobretudo a partir dele.

A Idade Média cristã vai delinear com contornos mais definidos os parâmetros ético-religiosos em que a política se desenrola. Muitos são os tratados que então se escrevem para a educação de príncipes ou para a orientação de reis ou de personalidades no uso de funções governativas. Poderá mesmo dizer-se que, a par dos Livros de Horas, foram os primeiros livros de reflexão moral e de formação de leigos.

O carácter formativo destes textos presidia à intenção primeira da sua elaboração e do seu uso. A sua mensagem dirigia-se ao enaltecimento das virtudes cardeais - e entre elas a justiça, como a primeira entre todas - , e ao encorajamento do vigor militar e guerreiro. $\mathrm{O}$ ideal cavaleiresco encontra nestas obras o seu guia, a expressão acabada do seu código de virtudes.

Nos séculos XII e XIII, esta literatura começa a seguir uma nova trajectória, 
caracterizada pela união dos ideais ético-políticos dos autores da Antiguidade clássica com os ideais, por assim dizer monásticos e guerreiros, que prevalecem na Idade Média. No entanto, a inspiração clássica já se afirmara, séculos antes, na época carolíngia. Aliás, foi com Carlos Magno que surgiram os tratados de educação de príncipes cristãos como género definido e independente.

As invasões bárbaras e os designados "séculos de trevas", que se contaram entre as duas Renascenças medievais, a carolíngia e a dos séculos XII-XIII, não podem contudo ser ignorados. É no século XIII, marco importante para a história das ideias políticas, que surge $\mathrm{S}$. Tomás de Aquino, intérprete fiel da mensagem aristotélico-ciceroniana e do direito romano. A importância e originalidade de que se reveste a doutrina política de $\mathrm{S}$. Tomás devem-se aos seus fundamentos jurídico e moral e à arte de utilizar conceitos da tradição patrística e de os elaborar, hamonizando-os com as novas orientações e directrizes do seu pensamento. O De regno ou De regimine principum ad regem Cypri (ca. 1265-1266) de S. Tomás e o tratado do mesmo nome de Egídio Romano vão ser cartilha a seguir por todo o governante e modelo literário de toda a tratadística futura até aos tempos modernos².

$\mathrm{Na}$ obra de $\mathrm{S}$. Tomás se encontra a formulação dos princípios gerais que definem uma democracia coroada pela teocracia: preferência pela monarquia electiva, onde o povo tem o direito de eleger o seu representante, o rei, cujas qualidades são fiança de o regime não degenerar em tirania, pelo que compete à colectividade, à autoridade pública, e em última análise ao poder da Igreja, e jamais a alguém individualmente, depor o tirano, sem praticar o tiranicídio ${ }^{3}$. Um aspecto moderno desta teorização sobre os deveres do poder real, que não aparece em Platão, Aristóteles ou Cícero e reflecte a orientação cristã da sua política, diz respeito à assistência aos desfavorecidos, à caridade pública ${ }^{4}$.

Apesar de as suas ideias se apresentarem pouco sistemáticas, ao longo das diversas obras, não se pode negar o pendor democrático dos preceitos enunciados que irá reflectir-se nos autores da chamada segunda escolástica, nos finais do séc. XVI, e é bem notório, entre nós, no tratado de D. Jerónimo Osório, Bispo de Silves, De regis institutione et disciplina (1572), escrito para a educação do jovem rei D. Sebastião $0^{5}$.

${ }^{2}$ Gilson 1983, 6a ed., III e partie: 313-435.

${ }^{3}$ De reg. princ. 1. 6-7.

${ }^{4}$ Ibidem, lib. 2.

${ }^{5}$ As reflexões políticas do Doutor Angélico encontram-se essencialmente na Summa Theologica, nos Comentários às Sentenças, no comentário que dedica à obra de Aristóteles e no De regimine principum. O seu Tratado das Leis, que se integra na Summa Theologica (I a-II ae -108), é um dos monumentos do pensamento da Idade Média, que esteve na base de tudo o que se escreveu sobre o assunto até ao séc. XVI - de recordar F. Suárez que o parafraseia, a cada passo - e mesmo ao longo do séc. XVII. Conhecida é a sua importância na obra de famosos teólogos e jurístas como D. Soto, O. P. (1494-1560), De iustitia et iure (Lugduni 1582), e.g. 1. 
A Idade Média não tinha conhecido a República de Platão: o pensamento do filósofo era divulgado apenas através de Compendia. A descoberta da Política de Aristóteles dá-se no séc. XIII. A obra de Diógenes Laércio, De uita et moribus philosophorum libri $X$, que ilustra todas as escolas filosóficas antigas, é encontrada nos primeiros anos de Quatrocentos ${ }^{6}$.

Os humanistas do primeiro Renascimento abandonam o Aristóteles lógico e físico, símbolo da barbárie estilística medieval ${ }^{7}$, e procuram na filosofia uma finalidade profundamente humana e um conteúdo mais vasto, que abarcasse motivos político-morais e os problemas da vida concreta da sociedade do tempo.

Este distanciamento do formalismo escolástico coincide com a reabilitação do neoplatonismo. É sem dúvida através do platonismo, configurado com o cristianismo, a ética aristotélica, ou mesmo com a tradição hermética e cabalística que os conceitos do saber medieval vão ser alvo de renovação.

Percebe-se a influência do platonismo em personalidades como Petrarca, o primeiro humanista, ou Pier Paolo Vergerio que se entrega ao estudo de Platão, com intuitos ético-pedagógicos ${ }^{8}$. Marsílio Ficino traduz a obra deste filósofo.

Concede-se então o maior relevo ao pensamento moral e político do Estagirita, conciliado com a doutrina platónica. Platão e Aristóteles lançam as bases teóricas e filosóficas de uma problemática política intemporal.

Aristóteles, apesar de considerações feitas em obras representativas como a Retórica, dedica especialmente à formação civil e política do homem de estado e do cidadão comum a Política, a Ética a Nicómaco e a Ética a Eudemo. Este filósofo da vida activa e educador de Alexandre, vai, segundo a tradição, servir de modelo no que se refere à origem da sociedade, às diferentes formas de constituição - com manifesta superioridade da monarquia -, aos processos de evitar as mutações, à caracterização do bom rei e do tirano, à organização dos poderes legislativo, executivo e judicial, à finalidade última do estado, o bem comum, traduzido no plano individual, social e público.

Por seu lado, Platão, na República, no Politico e nas Leis, com um carácter político acentuado, para além das preocupações deste teor, mais ou menos conscientes, que perpassam em todas as outras, é reconhecido pelos humanistas como mais religioso e mais profundo do que Aristóteles: a organização social que preconiza a aquisição das virtudes cívicas, em que sobressai a justiça resultante

I, qu. 3, a.1; 1. II, qu. 3, a. 8; 1. III, qu. 3, a. 3; B. Medina (1528-1580), Expositio in Primam Secundae Angelici Doctoris D. Thomae Aquinatis, Salmanticae, 1578; F. Suárez (1548-1619), De legibus ac Deo legislatore (Lugduni, 1613). Vide Soares 1994: 380-410.

${ }^{6}$ Vide e. g. a edição de Lugduni, Apud Antonium Vincentium, 1561. Sobre a vulgarização da obra de Diógenes Laércio, em Portugal, vide Carvalho 1949: 17-18

${ }^{7}$ Petrarca, principalmente no De sui ipsius et multorum ignorantia (1367), exprime a sua aversão ao formalismo escolástico dominado por Aristóteles e Averróis e invoca o pensamento de Platão, Cícero e Santo Agostinho.

${ }^{8}$ Vide Garin 1955: 339-374, maxime, p. 345-346; Idem 1966: I, II parte, caps. II e III. 
da harmonia entre todas elas são aspectos relevantes da sua filosofia política, recolhidas pelo Humanismo Renascentista9.

Notória é a complementaridade destes dois filósofos na forma como foram assimilados pelo pensamento moderno ${ }^{10}$. A importância conferida aos ensinamentos de Platão e Aristóteles, em matéria de pedagogia régia, é explicitamente revelada pelo humanista eborense André de Resende, no seu poema De uita aulica, dedicado a Damião de Góis, em 1535: Ille suo ingenio in sophiam propensus honestam/ quicquid Aristoteles argutus, quicquid amoenus/ dixerat ante Plato, mire cognoscere auebat, / ut melius quonam pacto foret ipsa gerenda/ publica res sciret, consultis utpote libris,/ Fallere quid nequeant, quod non adfectibus ullis/ subcumbant, quod nil sperent metuantue nec aequum/ calliditate mala faciant uideatur iniquum. ${ }^{11}$.

Os dois mestres da Antiguidade - em torno dos quais se gerou a polémica da sua superioridade relativa ${ }^{12}$ - vão ser lidos no original e compreendidos na profunda substância do seu pensamento: Leonardo Bruni Aretino traduz a Ética, a Política e o Económico de Aristóteles. Sucedem-se os comentários à obra do Estagirita, da maior importância na difusão do seu pensamento político-moral, por parte de humanistas, dos séculos XV e XVI, como Francesco Filelfo, Donaldo Acciaioli, Ermolao Barbaro, Francesco Piccolomini, Alessandro Piccolomini, Jacques Lefèvre d'Étaples, Melanchthon, John Case, Sebastian Fox Morcillo ${ }^{13}$.

A descoberta de obra de Cícero, as Epistulae ad Atticum, por Petrarca, em 1345, e as Epistulae familiares por Coluccio Salutati, além de provocar a controvérsia humanística sobre imperium e respublica - a glorificação de César ou de Bruto - , leva à discussão da figura histórica de Cícero, pensador e cidadão romano $^{14}$. O próprio Petrarca, que viu em Cícero um modelo de renúncia às

${ }^{9}$ Vide Touchard 1959: 29. e Pérez Ruiz 1984:257-295. Sobre o carácter "eudemónico" da filosofia moral da Antiguidade e a importância da mensagem espiritual de Platão, vide Sigeia 1970: 40.

${ }_{10}$ Vide e. g. Alessandro Piccolomini, na sua obra Della institutione morale libri XII (Venezia, 1583), considerada como síntese completa das ideias político-pedagógicas do século XVI; e Louys le Roy, comentador de Platão e Aristóteles, não com a intenção de esclarecer o seu pensamento, mas com o propósito de colher nos dois autores ensinamentos para a vida política.Vide Soares 1994: 215-216.

11 'O Rei [D. João III], por sua inclinação, propenso à honesta sabedoria, tinha um grande desejo de conhecer o que haviam dito outrora o subtil Aristóteles, o agradável Platão, para melhor saber como gerir a república, pela consulta de livros que não podem enganar, visto como não sucumbem a parcialidades, nada ambicionam nem receiam, e não fazem, com má astúcia, que o justo pareça injusto.... Cf. Ramalho 1985: 197.

${ }^{12} \mathrm{~A}$ violenta disputa que, em meados do século XV envolveu vários humanistas, entre eles Giorgio Gemisto Pletone e Giorgio de Trebisonda, encontrou vitalidade ainda no séc. XVI, aquando da polémica que opôs Pierre de la Ramée, no seu ataque aos esquemas da lógica aristotélica, ao famoso jurista português António de Gouveia (Cf. deste autor o seu Pro Aristotele responsio adversus Petri Rami calumnias Paris, 1545).

${ }^{13}$ Vide Kristeller $19613^{\text {a }}$ ed.: 302 e 308-309.

${ }^{14}$ Vide Baron 1938: 84-89; Idem 1970: cap. VI, maxime, p. 135-143; Bentley 1987: 196197; Burke 1987, $3^{\circ}$ ed.: 38 . 
paixões que dominam na vida pública, escreveu a famosa carta de acusação à sua sombra no Hades ${ }^{15}$. Esta carta, que suscitou a defesa de Cícero por Coluccio Salutati em 1392, teve uma réplica em 1394 de Pier Paolo Vergerio que, em nome do próprio Cícero, defende o seu espírito cívico e empenhamento político ${ }^{16}$.

O sábio estóico das Tusculanae disputationes, que prendera a atenção da Idade Média, dá lugar ao homem político e ao enaltecimento da uita actiua ciuilis.

Coluccio Salutati, no De nobilitate legum et medicinae vai reflectir sobre o papel das leis na sociedade17. Para Salutati, a jurisprudência tinha como objecto a perfectibilidade do homem na comunidade social ${ }^{18}$. O estado era o quadro normal e necessário à actividade humana. As leis traduziam os valores supremos que deviam orientar essa mesma actividade. Assim, o universo moral confundia-se, na sua própria fonte, com o universo legal. A superioridade da vida activa sobre a contemplativa, defendida nesta obra, aparecia ligada a uma visão verdadeiramente política da vida humana.

A exaltação da vida da ciuitas, que as leis ordenavam ao bem comum, pertence à tradição aristotélico-tomista que dominou a política de inspiração cristã, característica deste período. Além disso, a convergência do pensamento moral de Aristóteles com a doutrina platónica, defendida já por Giovanni Pico della Mirandola, é bem manifesta na obra de Salutati, significativa na orientação ideológica humanista.

Sob o signo do franciscanismo e do scotismo, Salutati será o pregoeiro do ideal de vida activa e integrará com Leonardo Bruni, seu discípulo, e Leon Battista Alberti a primeira geração do humanismo civil italiano. Na verdade, grande é o alcance do movimento cultural florentino ${ }^{19}$. A obra de Pier Paolo Vergerio e a modernidade do seu pensamento no De monarchia revelam bem a renovação ideológica então operada ${ }^{20}$.

${ }^{15}$ Petrarca 1942 3a ed.: vol IV: 226 sqq. (Ep. XXIV).

${ }^{16}$ Vide Vergerio 1934: 436-445.

${ }^{17}$ Coluccio Salutati é também autor de um tratado De tyranno, onde dá uma definição objectiva de tirania, tal como Bártolo, na linha do Defensor pacis (1324) de Marsílio de Pádua, um dos jurisconsultos mais célebres da sua época. ODefensor pacis, apoiado nas doutrinas de Aristóteles e de S. Tomás, contribui para a vitória das doutrinas democráticas, ao afirmar que o povo, a universitas civium, é a fonte de autoridade, a pars valentior. Marco importante no desenvolvimento da controvérsia ideológica, que opôs partidários e adversários do papado e do império, esta obra corresponde a uma tomada de consciência progressiva por parte dos pensadores medievais dos problemas da soberania e do estado. O crescimento da força e do papel dos estados, cuja ascensão é paralela ao declínio do papado e do império, é notório até ao século XVI, altura em que aparecem firmemente estabelecidos. Sobre o fervilhar das novas ideias no século XIV e os teorizadores dos novos estados, vide N. Soares 1994: 75-79.

${ }^{18}$ Cf. Ullman 1980: 209 e sqq.

${ }^{19}$ Baron 1970: 485.

${ }^{20}$ Baron 1970:140 e sqq. Embora com o mesmo nome, a obra de Dante, De monarchia (1311), mantém o princípio da superioridade espiritual do papa sobre o imperador, na linha dos pensadores teocráticos contemporâneos, e parte da universalidade do género humano para expor de forma leve e agradável as razões em favor da monarquia universal. Estas razões 
A par deste humanismo florentino de cunho cívico, florescia o humanismo paduano como exemplo de uma cultura civil fundida com o classicismo, desde os tempos de Albertino Mussato, nos inícios do séc. XIV. Isto, apesar de Pádua e Bolonha se tornarem conhecidos centros de irradiação do aristotelismo averroísta, defensor de um saber apoiado nas categorias lógicas, de carácter puramente especulativo, sucedâneo do medieval.

O desabrochar para uma nova era vem acompanhado de um enorme interesse pela educação e pela formação de uma sociedade renovada. É neste contexto que o ideal do príncipe perfeito do Renascimento vai ter origem. Ao próprio Petrarca cabe a formulação deste ideal no seu De republica optime administranda liber, seguido de um De officio et uirtutibus imperatoriis liber ${ }^{21}$. Petrarca, na verdade, "aveva stabilito un modelo umanistico con uno spechio per i principi, dedicado a Francesco il Vecchio Da Carrara nel 1373”22.

Em Portugal, na dinastia de Avis, a leitura de Regimentos de principes era considerada essencial à formação do governante, como dá a entender o passo da carta dirigida pelo infante D. Pedro a D. Duarte, por ocasião da sua subida ao trono ${ }^{23}$.

Era o hábito da leitura de obras adequadas ao ofício real uma das preocupações básicas da formação do príncipe da Idade Média, como prova já, no séc. XII, a teorização do Policraticus (VI) que chega a afirmar Rex illiteratus quasi asinus coronatus, expressão esta que, no séc. XV, Cristina de Pisano, em Songe $d u$ Vergier (I, 132) vai adaptar ao seu estilo, cheio de frescura e graciosidade: "Un roy sans letture est comme un nef sans aviron et comme ung oiseau sans ales".

A expressão usada pelos escritores medievais vai ter enorme fortuna entre os humanistas, a ponto de Gioacchino Paparelli afirmar: "E diverrà popolarissimo fra gli umanisti il motto caro a colui che resterà un tipico esempio di principe umanizzato, Alfonso il Magnanimo: Un re non letterato è un asino coronato"24.

Entre nós, Frei Heitor Pinto, no Diálogo da justiça, referindo-se ao prelado que identifica, pela sua função, com o príncipe -, vai traduzir e adaptar da forma seguinte a expressão do Songe du Vergier: "Prelado sem letras é ave sem penas, e navio sem leme, e relógio sem pesos" 25 .

A diferença de sentido destas expressões, usadas em épocas distintas, residia apenas no programa educativo que lhes era subjacente e a que implicitamente se reportavam.

tocaram Maquiavel que, com os ensinamentos ministrados no seu $\mathrm{Il}$ principe, acredita poder instaurar essa poderosa monarquia, sob a chefia de um príncipe italiano.

${ }^{21}$ Vide Petrarca (1581): 372 sqq. e 386 sqq.

${ }^{22}$ Cf. Baron 1970: 146.

${ }^{23}$ Cf. Carta inserta por Rui de Pina, na Chronica do Senhor Rey D. Duarte, cap. IV. Cf Pina 1970: 496.

${ }^{24}$ Paparelli 1973:100.

25 Pinto 1952: 166. 
Jacques Krynen, na sua obra sobre os tratados de educação de príncipes na Idade Média tardia, refere a importância que se dá, a partir da renascença das letras, no século XII, à cultura do príncipe ${ }^{26}$.

As leituras recomendadas pelos diversos autores desta época, quer de obras religiosas, morais, históricas, políticas ou militares visavam sempre a aquisição de uma sabedoria política ${ }^{27}$. Assim se compreende a grande importância que os Regimentos de principes, compostos com esse fim, teriam na formação do jovem rei.

Gomes Eanes de Azurara, na Chronica do Conde D. Pedro de Menezeses, dá-nos notícia, através da alocução proferida por D. João I em Ceuta aos membros que iriam permanecer na praça, que o Regimento de principes de Egídio Romano era lido na câmara real perante os fidalgos. Vários destes Regimentos de principes se encontravam na relação dos livros pertencentes à biblioteca do rei D. Duarte ${ }^{29}$. Isto, se para tanto não bastasse a obra que nos legou, o Leal Conselheiro, repassado de afinidades ideológicas com este género de literatura ${ }^{30}$. Se acreditarmos em Rui de Pina, o infante D. Pedro "tirou de latym em linguajem o Regimento de Pryncipes, que Frey Gil Correado compos, e assy tirou o livro dos Offycios de Tullio, e Vegecio de Re Militari, e compos o livro que se diz da Virtuosa Benfeytorya." ${ }^{31}$.

Na verdade, a produção literária dos príncipes de Avis, mesclada de citações da Sagrada Escritura e de autoridades do mundo antigo ou medieval, apresenta-nos os próprios príncipes e reis a reflectirem nos valores humanos, requeridos a todo o cidadão, e na própria condição da realeza, como outrora fizera Marco Aurélio.

D. Afonso V vai ser educado por mestres italianos, Estêvão de Nápoles e Mateus Pisano, o famoso autor do De belli Septensi ${ }^{32}$, que Zurara qualifica de "poeta laureado, e hum dos suficientes Filosofos e Oradores que em seus dias concorreram na christandade" ${ }^{3}$. Este monarca chama à corte Fr. Justo Baldino, doutor in utroque iure para narrar em latim os feitos dos Portugueses ${ }^{34}$. Faleceu antes de realizar a sua empresa.

\footnotetext{
${ }^{26}$ Krynen 1981: 97 e sqq.

${ }^{27}$ Ibidem, p. 100.

28 Serra 1972: 237-249.

${ }^{29}$ Sousa 1946-1954: 257-259.
}

${ }^{30}$ Vide sobretudo os capítulos L e LIII, que dizem respeito à educação do príncipe. A par da edição latina, a versão castelhana de Frei Juan García de Castrojeriz (Sevilha, 1494) do De regimine principum de Egídio Romano poderia ter sido usada por D. Duarte, ao compor o seu Leal conselheiro, em especial os capítulos L e LI, no que toca à virtude da prudência. Aliás a obra de D. Duarte abunda toda ela em citações daquele tratado. Sobre os muitos autores que chamaram a atenção para este facto, vide. Rebelo 1983: 96 e sqq.

${ }^{31}$ Pina 1977: 754.

${ }^{32}$ Zurara 1972: 215.

${ }^{33}$ Cf. Gomes 2006

${ }^{34}$ Cf. a carta de Ângelo Policiano a D. João II em tradução de Epifânio da Silva Dias in Carvalho 1947-1948: 25-27. 
Assim, quando o movimento humanista se inicia em Itália, ali se encontrava um escol português de eclesiásticos e embaixadores, junto da cúria, ou de estudantes que cursavam as universidades de Siena, Pádua, Pavia e Bolonha, famosas pelo estudo do Direito.

A sociedade portuguesa, estruturada até então segundo o modelo da hierarquia eclesiástica ${ }^{35}$, inicia uma renovatio, nos vários domínios da cultura, que pretendia garantir a consolidação da consciência nacional, de acordo com as solicitações do mundo civilizado de então, de que a corte de Borgonha dava o exemplo ${ }^{36}$.

A intensificação das relações comerciais com a França, a Flandres, a Itália e os contactos mais estreitos com a Inglaterra, país de origem de D. Filipa de Lencastre, e com Castela, centro de unidade cultural peninsular, favoreceram a abertura de um país que o feudalismo mantivera sobretudo voltado sobre si mesmo.

Um novo conceito de estado e da função do governante se começava já a esboçar: "conviviam, pois, ainda na geração de Avis, o antigo e o moderno. Mas a marcha do futuro estava encetada" ${ }^{37}$.

Caberá ao Renascimento sintetizar e desenvolver muitos dos princípios, latentes já no final da Idade Média.

O interesse que o direito romano suscitava na Europa, a partir da primeira metade do séc. $\mathrm{XII}^{38}$, de que foram intérpretes os primeiros humanistas ${ }^{39}$, foi um dos aspectos essenciais na evolução do processo histórico ${ }^{40}$. Segundo Nuno J. Espinosa Gomes da Silva, a Idade Média aparecia concretizada aos olhos da Renascença como época que vivera o direito romano justinianeu, na sua interpretação lentamente destilada por glosadores e comentadores" ${ }^{{ }^{41}}$. Caberá aos humanistas iniciar a restitutio do Corpus Iuris ${ }^{42}$.

A communis opinio, que se impunha aos juristas medievais como critério de verdade, é substituída pela perícia interpretativa dos humanistas, com base no conhecimento das bonae litterae e no uso da ciência dialéctica. Em Itália, Lorenzo Valla, e a seguir Angelo Poliziano são os primeiros a aplicar o método filológico na interpretação do direito justinianeu, cheio de incoerências e aspectos nebulosos.

${ }^{35}$ Vide o ordenamento social das classes, estabelecido nas Ordenações Afonsinas in Peres 1952. 271. Sobre o conceito da nossa realeza medieval, o artigo de P. Merêa "Organização social e administração pública” in 1929. (vol. II, terceira parte, p. 461, col.2); Huizinga 1948 (cap. III) sintetiza de forma bem elucidativa a concepção teológica e política da hierarquizada sociedade medieval.

${ }^{36}$ Vide Monfrin 1964.

${ }^{37}$ Vide Albuquerque 1983: 153.

${ }^{38}$ Vide Ullmann 1980: cap. II: "La secolarizzazione del governo", maxime, p. 52-72; N. J. E. G. da Silva 1964: 31 e sqq.

${ }^{39}$ Ullmann 1980: 71; 136 e 222-225; F. Colasso 1951: 57-58.

${ }^{40}$ Ullmann 1980: 208-209.

${ }^{41}$ Ibidem: 31.

${ }^{42}$ Ibidem: 35. 
Também em Portugal se verificou o incentivo do estudo do Direito, nos alvores do nosso humanismo, com preferência pelas Universidades de Itália, onde a ciência jurídica concorria com a cultura das letras ${ }^{43}$.

Foi o direito romano o primeiro factor a favorecer a secularização, de importância capital na evolução do conceito de estado e da função do governante ${ }^{44}$. Contudo, várias linhas de força convergiram no sentido desta evolução: o direito romano, o bartolismo, o aristotelismo político, o laicismo ${ }^{45}$.

À concepção teocrática medieval, Walter Ullman opõe o modelo do principe "umanizzato" do Renascimento, que não se cinge à simples imitação do passado, mas desenvolve e adapta as funções do imperador tardo-romano às exigências do seu reino ${ }^{46}$.

$\mathrm{Na}$ verdade, enquanto na Idade Média se considerava o direito como emanação de uma lei natural, identificada com a vontade divina, e se sujeitava o estado aos ditames universalísticos dessa lei, no Renascimento é a vida, são as exigências do estado que vão levar à sua formulação ${ }^{47}$. Diz J. A. Maravall: "Lo cierto es que desde los siglos bajomedievales, siglos de preparación de las nuevas formas políticas, hasta la época del Renascimiento, uno de los factores que participan eficazmente en la evolución del Estado moderno es del derecho particular o estatalizado"48. A lex omnium generalis em que se apoiava a jurisdição do estado medieval vai dar lugar ao ius proprium, que implica "la voluntad del príncipe proprio" 4 .

Entre nós, comprovam este facto de forma bem evidente as Ordenaçóes régias, pela primeira vez publicadas em meados do séc. XV (1446-1448), no reinado de D. Afonso V, que, a partir de então, assumem um papel de relevo na estrutura governativa portuguesa. Além disso, as cortes começaram a ser convocadas cada vez menos frequentemente, sobretudo a partir de D. João II, o que comprova a progressiva centralização de poderes e entre eles o poder legislativo na pessoa do rei ${ }^{50}$. O florescimento das humaniores litterae fundou-se na ânsia de conhecer a conduta do homem no mundo antigo, para dela extrair paradigmas. Assim se desenvolveu o estudo da ciência política.

Como observa Walter Ullman, um aspecto deve ser evidenciado: praticamente todos os primeiros humanistas foram juristas ${ }^{51}$. É que "L'umanesimo trovò

${ }^{43}$ Ibidem: 112 e sqq.; V. Rau 1969: 185-201.

${ }^{44}$ Ullmann 1980: 70-71.

${ }^{45}$ Vide Albuquerque 1983: 151-152 e os passos da obra de Walter Ullmann em que se apoia.

${ }^{46}$ Ullmann 1980: p. 70-71.

${ }^{47}$ Vide Moncada 1974: 89-92.

${ }_{48}$ Maravall 1972: II, 412.

${ }^{49}$ Maravall 1972: 414-415.

${ }^{50} \mathrm{D}$. João I, eleito por vontade popular, convocou as cortes vinte e cinco vezes; D. Duarte, no seu breve reinado de seis anos, quatro; D. Afonso V, vinte e duas; D. João II, quatro. D. Manuel, durante um reinado de vinte e seis anos, convocou-as quatro vezes; e D. João III, que reinou durante trinta e um anos, apenas três vezes.

${ }^{51}$ Ullmann 1980: 225. 
la sua primitiva espressione in connessione con il rinascimento del cittadino in quanto membro integrante della (nuova) idea dello stato" ${ }_{52}$.

É sobretudo no tempo de D. João II que a cultura jurídica de formação italiana conhece grande prestígio, em Portugal. No seu fascínio pela Itália, o nossa monarca, além das relações estabelecidas com a corte de Médicis e com Poliziano, convida para desempenhar os cargos de orator regius e de preceptor de D. Jorge, seu filho bastardo, o italiano Cataldo Parísio Sículo - Doutor em Direito pela Universidade de Ferrara e mestre na de Bolonha -, considerado o introdutor do Humanismo em Portugal.

Manda os primeiros bolseiros portugueses estudar às universidades italianas, onde floresciam as humaniores litterae: os filhos de João Teixeira, Aires Barbosa, Henrique Caiado, Martinho de Figueiredo, Gaspar Vaz, entre os principais. Eles abririam caminho a muitos outros que, ajudados por D. Manuel e D. João III se viriam a formar nas escolas mais famosas de então. São estes juristas, entusiastas decididos da renovação humanista em Portugal, seguidores dos métodos interpretativos de Valla e Poliziano e do espírito cívico que impregnou a sensibilidade dos homens do Quattrocento.

Curioso é que, entre os bolseiros do rei, o poeta elogiado por Erasmo, Henrique Caiado - que troca o estudo das Leis pelas Letras e ataca, nas suas Eclogae, a seditiosa cohors de causídicos que superam em riqueza os próprios reis, Reges diuitiis superent ${ }^{53}$ - é autor de uma oração em louvor da jurisprudência.

Esta obra tem para nós o interesse de revelar Caiado como um fiel discípulo do ideal cívico do humanismo italiano. Como Petrarca e Salutati faz a exaltação da vida activa, do facere subordinado à ratio e ao consilium, a apologia da interpenetração do ius e da ciuitas, da indispensabilidade do direito à rei publicae gubernatio.

Se Bártolo, Baldo e Acúrsio continuam a ser autoridades entre nós, como diria André de Resende com verdade, o certo é que o método jurídico medieval tinha sido ultrapassado ${ }^{54}$. Neste particular, é já claro o Regimento da Instituta de $17 \mathrm{de} \mathrm{Se-}$ tembro de $1539^{55}$, em que D. João III impõe ao ensino das Leis, na sua Academia, a razão acima das autoridades, a opinião reflectida e avisada do jurista acima da communis opinio, escamoteada por glosadores e comentadores da época precedente.

Além disso, por alvará 26 de Outubro de 1541, ordena este monarca a leitura de S. Tomás, em vez de Durando, na Universidade de Coimbra, cabendo

${ }^{52}$ Ullmann 1980: 137.

${ }^{53}$ Vide Caiado 1745: 217 (Epigramma XLII, Ad Bart. Blanchinum); 154 (Epigramma XXIII, Ad Benedictum Barbatiam). Sobre a crítica à prática jurídica na pena de Henrique Caiado, vide também N. J. Silva 1964: 149 e sqq. Tema recorrente no século XVI é a crítica à ambição dos causídicos, designados ironicamente por "causíficos".

${ }^{54}$ Vide André de Resende, De uita aulica, composta em 1535 e publicado em Lovaina em 1544 com dedicatória a Damião de Góis. Cf. Freire (ed.) 1916: 142.

55 Brandão 1937: 188 (doc. CXIII); cf. também, neste particular, Leite (ed.) 1963: 99 (cap. 31, Do modo que lerão os lentes de cadeiras piquenas de Canones e Leis e Instituta). 
o magistério desta primeira cátedra de Teologia a Martin de Ledesma, um dos discípulos mais famosos de Francisco Vitória, na conhecida Escola jurídica de Salamanca.

O humanismo não irrompeu abruptamente, como movimento novo e antagónico às concepções tradicionais do mundo medieval. Não houve de forma alguma solução de continuidade, nem antítese entre as duas mentalidades: foi antes a humanística a "sublimação última da intuição medieval" ${ }^{6}$.

É assim que, no que se refere à fundamentação do poder político, o tomismo e o bartolismo dominaram o pensamento dos nossos humanistas, cuja nova intuição da vida se afirmava em diversos campos, onde era grande a força da tradição $0^{57}$. Importa referir, todavia, que a doutrina tomista era válida apenas nos aspectos em que, por assim dizer, traduzia em termos teológicos a concepção clássica da política e da moral.

A fórmula do direito romano que liberta o governante de obedecer à lei que promulga, quod principi placuit, legibus habeat uigorem ${ }^{58}$, ou princeps legibus solutus est ${ }^{59}$, que se encontra em $\mathrm{S}$. Tomás ${ }^{60}$ - salvaguardada embora pelo príncipio de que só é verdadeiro príncipe aquele que se conforma à lei da razão (o que justificava o direito de resistência) - não figura, em regra, na obra dos humanistas. Defendida a lex regia no século XIV por Cola de Rienzo, é posta em causa desde o Quattrocento italiano ${ }^{61}$. De interesse é a observação de Salutati, que vê nela a base do arbítrio do legislador e do governante e o reconhecimento da relatividade do direito positivo ${ }^{62}$.

Nesta linha, o princípio ulpiano é discutido pelos nossos tratadistas que, seguindo uma tradição que entronca nos autores da época helenística ${ }^{63}$, afirmam - à semelhança de Erasmo: Nec protinus lex est, quod principi placuit ${ }^{64}$ - a subordinação do príncipe à lei.

Mesmo quando o conhecimento da posição dos romanistas condiciona a

${ }^{56}$ Vide Colasso 1951: 59.

${ }^{57}$ Sobre a dívida do Renascimento para com a obra de S. Tomás e Bártolo de Sassoferrato, vide Ullmann 1980: 157-158 e 180 e sqq.; Sforza 1951: 71. Sobre a sua influência entre nós, vide Andrade 1959: 5-8 e sqq.; Albuquerque 1981: 41-61.

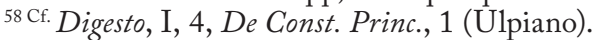

${ }^{59}$ Dig. I. 3.31 .

${ }^{60}$ Summa Theologica, Ia - IIae, qu. 90, a.1.3. Ibidem, Ia-IIae, qu. 96, a.5.3. Vide a análise de J. de la Croix Kaelin O. P., in S. Tomás de Aquino 1946: 25-29. Sobre a obrigatoriedade de o príncipe estar sujeito à lei no que diz respeito à uis directiva, embora não dependente dela no que toca unicamente à uis coactiva, vide J.-M. Aubert 1955: 83-84.

${ }^{61}$ Vide e.g. o primeiro grande tratadista do Quattrocento italiano, Francesco Patrizi (Senense). No seu De regno et regis institutione (II, 1) afirma que o príncipe é ius animatum e por isso seria iníquo se não obedecesse às leis que ele próprio prescreve aos outros (VIII, 6). Sobre esta obra, vide G. Chiarelli 1932: 716-738.

${ }^{62}$ Vide Sforza 1951: 72.

${ }^{63}$ Vide e. g. Platão, Lg. IV, 715b; VI, 775a-c, 762d, etc.

${ }^{64}$ Erasmo, Institutio principis christiani, L. B., IV, 595 F. 
expressão de autores como Lourenço de Cáceres, em que é evidente uma situação de compromisso, a fidelidade do príncipe a lei não é abalada ${ }^{65}$.

João de Barros, no seu Panegírico de D. João III, afirma: "[...]por isso quer Platão que o príncipe obedeça em tudo às leis; e diz que onde a lei é sujeita ao rei e não o rei à lei, se deve recear que aquele reino se perca mui asinha; porque, quando governa a lei, governa Deus - o que não pode ser quando se tudo manda pelos apetites de um homem"66.

Diogo de Teive na Institutio Sebastiani Primi, ou Regras para a educação de El-Rei D. Sebastião, exprime mesmo a sua oposição ao princípio do direito romano ${ }^{67}$ : "Obedece o Rei às leis santissimas, / Obedece à razão e à justiça / O Tyranno à vontade, e appetite"// "Nem queira fazer tudo quanto póde, / Mas só quanto convém, quanto for justo, / $\mathrm{E}$ aqui de seu poder ponha os limites, / E entenda que também fica subjeito /Às leis que ele mandou que se guardassem, / Bem ao contrário do que n'outro tempo/.../ Aquella lisongeira lei mandava, / Que os Reis das suas leis isentos fossem".

Bem expressivos a este respeito são Diogo de Sá, em Tractado dos Estádos Ecclesiasticos e seculares ${ }^{68}$, D. Jerónimo Osório, em De regis institutione et disciplina, ou os juristas Manuel Soares da Ribeira, Gonçalo Mendes de Vasconcelos e Jorge de Cabedo, entre outros ${ }^{69}$.

Dirá Martim de Albuquerque: "o modo como em Portugal no século XVI foi encarada a temática das relações entre o rei e a lei, permite-nos concluir que - para lá de todos os debates e subtilezas doutrinais -, permanece, como princípio fundamental, a ideia de que o monarca deve também cumprir as próprias normas"70.

Apenas Diogo Lopes Rebelo, defensor do absolutismo do monarca - exemplo de virtudes - vai ter em mente este postulado, tal como Guillaume Budé na sua Institution du prince, dedicada a Francisco I ${ }^{71}$. Com efeito, no De republica gubernanda per regem, Lopes Rebelo afirma que o rei é, no seu reino, por direito divino e humano, senhor da vida e da morte dos seus concidadãos: Rex enim in suo regno iure diuino et humano, uitae et necis hominum dominus est ${ }^{72}$. A pesar disso, não deixa de explicitar que os reis não podem promulgar leis contra o direito divino e que a lei iníqua não merece o nome de lei $^{73}$.

${ }^{65}$ Vide Sobre os trabalhos do rei de Lourenço de Cáceres, in Andrade 1965: 65.

${ }^{66}$ Barros 1937: 7.

${ }^{67}$ Teive 1756: 74-75 e 150-151.

${ }^{68}$ Sá, Tractado dos Estados Ecclesiásticos e Seculares. Em que por muy breue e claro stillo se mostra como em cada hum deles se pode o Christão salvar. Author Diogo de Saa. Nelle se impugnão muitas heresias que muitos hereges teverão em cada hum dos estados, Ms. da B. N. L., F. G.2725, p. 234-235.

${ }^{69}$ Albuquerque 1968: 280 e sqq.

${ }^{70}$ Ibidem: 271.

${ }^{71}$ Vide Institutione du Prince, fos. $7 v^{\circ}-8 \mathrm{r}^{\circ}$, edição de Bontems 1965: 80. Sobre a defesa da monarquia absoluta por Budé, nesta obra e no De asse, Ibidem: 24-34.

${ }^{72}$ Cf. Rebelo 1951: 66-67.

${ }^{73}$ Vide a este propósito, Albuquerque 1968: 298-299. 
A posição assumida por este tratadista, e mais veementemente por Guillaume Budé, difere, contudo, da perspectiva de S. Tomás e reflecte bem a tendência para o reforço do poder real ${ }^{74}$, que começa a desenvolver-se no Renascimento e ganha vulto com a obra de Jean Bodin, Les six livres de la Republique, de $1576^{75}$.

O século XV, em que crescera e se formara Maquiavel, nascido em 1469, assistira à tirania cheia de astúcia de um Luís XI, ao despotismo violento personificado em Carlos o Temerário, à posição política de um Gerson e de um Jean Petit, ou de um Philipe de Commines, historiador e conselheiro de Luís XI, à pregação, cheia de fanatismo do reformador religioso, Savonarola. ${ }^{76}$

Foi já observado que o idealismo e o arrebatamento político-religioso de Savonarola teria condicionado o tom realista e incrédulo de Maquiavel que, por ver os esforços vãos do seu compatriota, se teria decidido a trilhar o caminho oposto ${ }^{77}$. $\mathrm{Na}$ verdade, a obra Il principe (1513), publicada apenas em 1532 e dedicada a Lourenço de Médicis, reflecte pelo menos a realidade da época conturbada em que viveu.

Bem diverso do príncipe "umanizzato" é o modelo de governante proposto por Maquiavel, confessado inovador neste domínio, ao apresentar em Il principe as condições técnicas necessárias à conquista do poder e à permanência nele ${ }^{78}$. No entanto, as doutrinas do Florentino não provocaram reação apreciável até cerca de meados do séc. XVI, nem influenciaram a concepção humanista do modelo do príncipe, na literatura europeia e de forma particular na Península Ibérica - menos aberta a inovações que viessem pôr em causa o compromisso entre a moral e a política. O Florentino, como tem sido afirmado, abre a era dos filósofos políticos modernos, como Hobbes, Spinoza, Pufendorf e prefigura o estado racional que Hegel viria a definir ${ }^{79}$.

$\mathrm{Na}$ mesma altura em que Maquiavel condensa em Il principe as suas conclusões políticas da Renascença italiana, Erasmo, nos países do Norte, exprime também, através de teorias ético-jurídicas, uma concepção bem diversa do

${ }^{74}$ Cf. Allen 1951: 281-282; Merêa 1941: 26; e introdução a Rebelo 1951: XXV.

${ }^{75}$ Esta obra de doutrina e teorização jurídico-política, que parte da reflexão crítica dos modelos da Antiguidade geco-latina e do direito romano, vai ser um marco importante para a produção política posterior. Vide Soares 1994:141-142.

${ }^{76}$ Curioso é que o futuro Chanceler de Florença fora, jovem ainda, um simpatizante da doutrina de Savonarola, cujos seguidores, os piagnoni, se opunham aos arrabbiati, defensores do governo dos Médicis.

${ }_{77}$ Vide Franck 1864: 337.

${ }^{78}$ Vide Il principe, cap. XII e sobretudo XV. Depois de investigar, no cap. XII, os meios pelos quais muitos adquiriram e conservaram o poder, conclui, no cap. XV, que um príncipe para se manter no governo deve aprender a nem sempre ser bom, para passar a ser conforme as circunstâncias e os interesses o exigirem. Mas é sobretudo nos capítulos XV-XIX, que se verifica uma ruptura definitiva com a ética aristotélica e os princípios apregoados pelo estoicismo, vivificado pelo cristianismo.

${ }^{79}$ Vide e. g. Maquiavel 1980: 108 e 155; Stegmann 1977: 498. 
homem $^{80}$. E Tomás Moro, o amigo dilecto de Erasmo, publica a sua Utopia (Lovaina, 1516), que apresenta o plano de uma república ideal, assente nos principios da moral tradicional e nos valores de uma renovada filosofia antropológica, neo-platónica, tão cara ao Humanismo Renascentista.

A Institutio principis christiani de Erasmo e a Utopia de Tomás Moro, editadas no mesmo ano, que representam as duas facetas neoplatónicas do idealismo político-social e religioso do humanismo europeu, estão na base de quantas se escreveram sobre o mesmo tema. Diríamos mesmo que a obra de Erasmo deu o tom a toda uma abundante literatura - os tratados de educação de príncipes dentro da linha católica ortodoxa, que este século conheceu.

A atitude de oposição a Maquiavel ou aos autores reformistas, ou ainda a preocupação de orientar os príncipes dos diversos estados, salvaguarda dos interesses nacionais, postos acima dos interesses pessoais - que o absolutismo assente no regalismo romano favorecia - são os principais factores responsáveis pela enorme proliferação de tratados de educação de príncipes na Europa.

O importante papel que este tema assume na nossa literatura quinhentista implica que a sua ocorrência extravase em muito a tratadística tradicional. Está presente nas orações pronunciadas em cortes ou em juramentos de príncipes; em orações de entrada ou ainda em orações universtárias, em panegíricos; nos textos poéticos dos vários autores, desde o Cancioneiro Geral e Gil Vicente a Sá de Miranda, António Ferreira, Camões e tantos outros que, em língua portuguesa ou na latina, dedicaram os seus versos a reis, príncipes e figuras de relevo na governação; nas composicões dramáticas em verso e em prosa, nas tragédias plenas de teorização política e admoestação, nas comédias cheias de sátira social e denúncia de costumes depravados.

Apesar da leitura global da mentalidade colectiva da época, que esta produção apresenta, nela sobressai o eterno catálogo de virtudes, referência imutável que precede o olhar do pintor que traça o retrato do príncipe ideal e o condiciona ${ }^{81}$. As virtudes humanas, de cariz cínico-estóico, configuram-se com as virtudes cardeais do Cristianismo - justiça, fortaleza, temperança e prudência -, a que se ligam muitas outras que lhes são indissociáveis, lhes especificam o sentido e lhes conferem uma mais ampla dimensão humana e transcendental ${ }^{82}$ tal como no desenho preparatório do Carro triunfal de Maximiliano I de Dürer ${ }^{83}$.

Imbuído de platonismo, este ideal do governante, modelo de virtudes, justo e bom administrador da justiça - simbolicamente, representante de Deus na

\footnotetext{
${ }^{80}$ Vide e.g. Mesnard 1977: 86-140.

${ }^{81}$ Vide Krynen 1981: 54 e sqq.

${ }^{82} \mathrm{O}$ chamado cânone das virtudes cardeais foi enunciado pela primeira vez em Píndaro, $I$. 8. 50-56. Cf. também Platão, $R$., 504a sqq.

${ }^{83}$ Vide Soares 1994: 190-197.
} 
terra, qual sol que a todos ilumina. no dizer de Frei Heitor Pinto ${ }^{84}-$, que na sua majestas encarna o poder como lei animada, nómos émpsychos, e, na sua magnificentia/ magnanimitas, se impõe como norma de conduta e acção moral, é o ideal do homem do Renascimento e de todos os tempos, que Giovanni Pico della Mirandola exalta em De hominis dignitate.

No que se refere à justiça que, segundo Platão, inclui e resume todas as outras, a ela se ligam a clemência e a verdade - a misericórdia. Essa misericórdia de que nos fala Shakespeare, em cena de tribunal, no Mercador de Veneza (acto

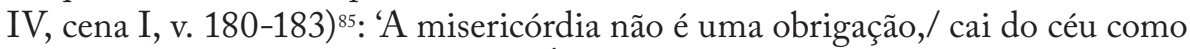
um frescor de chuva/ sobre a terra. É uma bênção dupla:/ abençoa quem a dá e quem a recebe 8 .

Numa palavra, ao considerarmos as relações dos humanistas com o poder, no contexto do Renascimento, assentes no direito e na ciência política - ancorados na mensagem da Antiguidade clássica, assimilada aos valores do Cristianismo -, poderemos com toda a razão observar que elas reflectem uma nova dimensão do humano, presente na ideologia e na doutrina que caracterizam a literatura do século de ouro português e europeu.

${ }^{84}$ Vide Soares 1994: 287.

${ }^{85}$ The Merchant Of Venice: «PORTIA The quality of mercy is not strain'd,/ It droppeth as the gentle rain from heaven/ Upon the place beneath: it is twice blest; It blesseth him that gives and him that takes».

${ }^{86}$ Este passo shakespeariano foi citado pelo Papa Francisco - neste ano Jubilar da Misericórdia -, ao afirmar, na sua mensagem para a 50ª Jornada Mundial das Comunicações Sociais, que a linguagem da misericórdia deveria permear também a política e a diplomacia e ser praticada por todos aqueles que têm responsabilidades institucionais. 


\section{Bibliografia Final}

AA.VV. (1990), Archéologie de la vigne et du vin. Actes du colloque 28-29 mai 1988, Paris.

AA.VV. (1992), Archeologia del paesaggio. IV Ciclo di lezioni sulla ricerca applicata in archeologia, Certosa di Pontignano (Siena) 14 - 26 gennaio 1991, Firenze.

AA.VV. (1997), Uomo, acqua e paesaggio. Atti dell'incontro di studio sul tema irreggimentazione delle acque e trasformazione del paesaggio antico, S. Maria Capua Vetere 22 - 23 novembre 1996, Roma.

AA.VV. (1998), El vi a l'antiguitat. Economia, producció i comerç al Mediterrani occidental. II Colloqui internacional d'arqueologia romana. Actes. Badalona, 6 - 9 de maig de 1998, Badalona.

AA.VV. (1999), El vino en la antigüedad romana. Simposio arqueología del vino, Jérez 2, 3 y 4 de octubre 1996, Madrid.

AA.VV. (1999b), Environmental reconstruction in Mediterranean landscape archaeology, Oxford.

AA.VV. (2001), La cerveza en la antigüedad, Sevilla.

AA.VV. (2004), Le vin. Nectar des dieux, génie des hommes, Gollion.

Abascal, J. Manuel, Espinosa, Urbano (1989), La ciudad hispano-romana. Privilegio y poder, Logronho.

Abásolo, J. A., Mayer, M. (1997), "Inscripciones latinas”, in S. Corchón (coord.), La Cueva de la Griega de Pedraza (Segovia), Zamora, 183-259.

Abbondanza, L. (ed.) (2008), Filostrato Maggiore, Milano.

Acosta-Hughes, B. (2002), Polyeideia. The Iambi of Callimachus and the Archaic Iambic Tradition, Berkeley and Los Angeles.

Adams, C. (2001), "There and back again. Getting around in Roman Egypt", in Adams, C. and R. Laurence (eds.), Travel and Geography in the Roman Empire, Londres and Nova Iorque, 138-166.

Adams, J. N. (2003), Bilingualism and the Latin language, Cambridge.

Adams, J. N. (2003a), “Romanitas and the Latin language”, CQ 53: 184-205.

Affatato, R. (2010), "Nueva York: recepción del mito de la ciudad en Federico García Lorca e Italo Calvino", in J. M. Losada Goya (ed.), Mito y mundo contemporáneo. La recepción de los mitos antiguos, medievales y modernos en la literatura contemporánea, Bari, 627-640.

Albuquerque, M. de (1968), O poder politico no Renascimento português, Lisboa.

Albuquerque, M. de (1981), "Bártolo e bartolismo na história do direito português”, Boletim do Ministério da Justiça 304: 41-61.

Albuquerque, M. de (1983), Estudos de cultura portuguesa, I, Lisboa. 
Alexandrescu-Vianu, M. (1988), “O nouă posibilă genealogie a familiei lui Hippolochos, fiul lui Theodotod, de la Histria”, SCIVA 39.3: 275-280.

Alexandrescu-Vianu, M. (1989), "Apollon Ietros. Ein verschollener Gott Ioniens?”, IstMitt 39: 115-122.

Alexandrescu-Vianu, M. (1990), "Die Steinskulptur von Histria", in P. Alexandrescu, W. Schuller (eds.) Histria. Eine Griechenstadt an der rumänischen Schwarzmeerkünste, Xenia. Konstanzer Althistorische Vorträge und Forschungen 25, Konstanz, 179-232.

Alexandrescu-Vianu, M. (2000), "Une alternative d'identification de la statue colossale d'Istros", in A. Avram, M. Babeş (eds.) Civilsation grecque et cultures antiques périphériques. Hommages à $P$. Alexandrescu à son $70^{\circ}$ anniversaire, Bucarest, 274-281.

Alexandridis, A. (2004), Die Frauen des römischen Kaiserhauses. Eine Untersuchung ibrer bildlichen Darstellung von Livia bis Iulia Domna, Mainz.

Alfayé, S., Marco, F. (2008), "Religion, language and identity in Hispania: Celtiberian and Lusitanian rock inscriptions", in R. Häußler (ed.), Romanisation et épigraphie. Etudes interdisciplinaires sur lacculturation et lidentité dans l,Empire romain, Montagne.

Alföldi, A. (1948), The conversion of Constantine and Pagan Rome, Oxford.

Alföldy, G. (1969), Fasti Hispanienses, Wiesbaden.

Alföldy, G. (1973), Flamines provinciae Hispaniae citerioris, Madrid.

Alföldy, G. (1991), "Augustus und die Inschriften: Tradition und Innovation. Die Geburt der imperialen Epigraphik”, Gymnasium 98: 289-324.

Allen, A. (1951), History of political thought in the sixteenth century. London

Altaner, B., Stuiber, A. (2a ed. 1972), Patrologia, São Paulo.

Amouretti, M.C., Brun J.-P. (eds.) (1993), La production du vin et de l'buile en Méditerranée. Actes du symposium international organisé par le Centre Camille Jullian et le Centre archéologique du Var, Aix-en-Provence et Toulon 20-22 novembre 1991 (BCH suppl. 26), Athènes.

Ando, C. (2003), "A Religion for the Empire", in A. J. Boyle, W. J. Dominik (eds.), Flavian Rome. Culture, Image, Text, Leiden, Boston 323-344.

Ando, C. (2006), "Interpretatio Romana”, in L. de Blois, P. Funke, J. Hahn, (eds.), The Impact of Imperial Rome on Religions, Ritual and Religious Life in the Roman Empire, Proceedings of the Fifth Workshop of the International Network Impact of Empire (Roman Empire 200 B.C. - A.D. 476.), Leiden, Boston 51-65.

Andrade, A. A. (1959), S. Tomás de Aquino no periodo áureo da filosofia portuguesa, Lisboa.

Andrade, A. A. de (1965), Antologia do pensamento politico português (séc. XVI), vol. I. Lisboa. 
Andrade, M. (1974), "Lira Paulistana”, in Poesias completas, São Paulo.

Andreu, J. (2004), Edictum, Municipium y Lex: Hispania en época flavia (69-96 d. C.), BAR Int. Ser. 1293, Oxford.

Antonietti, C. (1999), "Megara e le sue colonie: unità storico-culturale?”, in C. Antonetti, P. Lévêque (eds.) Il dinamismo della colonizzazione greca, Atti della tavola rotonda "Espansione e colonizzazione greca di età arcaica: metodologie e problemi a confront", Venezia, 10-11/11, Besançon-Paris, 17-24.

Aquino, T. de (1946), Des lois de Saint Thomas d'Aquin. Texte traduit et présenté par J. de la Croix Kaelin O. P., Paris.

Arnaldi, A. (2010), “Osservazioni sul flaminato dei Divi nelle provincie africane”, in M. Milanese, P. Ruggeri, C. Vismara, (eds.), L'Africa romana. Luoghi e le forme dei mestieri e della produzione nelle provincie africane. Atti del XVIII convegno di studio. Olbia 11-14 dicembre 2008, vol. III, Roma, 1645-1665.

Arruda, A. M. (2005), "O 10 milénio a.n.e. no Centro e no Sul de Portugal: leituras possíveis no início de um novo século", O Arqueólogo Português Série IV: 23: 59-74.

Arzone, A. (2011), “Alcune considerazioni sulle immagini di pietre miliari e sui riferimenti alle strade nel documento monetale", in I miliari lungo le strade dell'Impero. Caselle di Somma campagna Verona, 77-92.

Asensi, R. M., Musso, O. (1990), "Un documento etrusco di Tarragona", Quaderni della sezione di Studi Storici Alberto Boscolo 1: 5-11.

Aston, M. (1997), Interpreting the landscape. Landscape archaeology and local bistory, London.

$A T L=$ B.D. Meritt, WadeGery, H.T., McGregor, M.F., The Athenian Tribute Lists, 4 vs, Princeton.

Aubert, J.-M. (1955), Le droit romain dans l'oeuvre de Saint Thomas, Paris.

Avery, H. C. (1971), "Euripides' Heraclidae", AJPh 92: 539-565.

Avram, A., Lefèvre, F. (1995), "Les cultes de Callatis et l'oracle de Delphes", REG 108: 7-23.

Bacchielli, L. (1986), "Monumenti funerari a forma di cupula: origine e diffusione in Italia meridionale", in A. Mastino (ed.), L' Africa Romana: atti del 3. convegno di studio Sassari 13-15 dicembre 1985, Sassari, 303-319.

Bailly, A. (1963), Dictionnaire grec-français, Paris.

Balass, G. (s.d.), "The Female Breast as a Source of Charity: Artistic Depictions of Caritas Romana", www.Academia.edu/4006836.

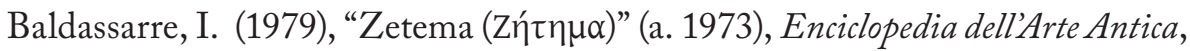
Suppl. 1979: 944-945.

Baldassarre, I., Bragantini, I., Morselli, C. and Taglietti, F. (1996), Necropoli di Porto. Isola Sacra, Roma. 
Balil, A. (1984-88), "Las cupae de Barcino. Contribución al estudio de un tipo de monumento funerario romano", Arqueologia e Historia: 111-115.

Baratta, G. (1993), “Una divinità gallo-romana. Sucellus. Un’ipotesi interpretativa”, ArchCl 45: 233-247.

Baratta, G. (1994), "Circa Alpes ligneis vasis condunt circulisque cingunt", ArchClass 46: 232-260.

Baratta, G. (1997), "Le botti: dati e questioni”, in Techniques et économie antique et médiévale. Le temps de l'innovation. Colloque international, Aix-enProvence 21-23 Mai 1997, Paris, 109-112.

Baratta, G. (1997), "Sucellus", in Enciclopedia dell'Arte Antica classica e orientale, Supplemento 1991-1994, V, Roma, 482.

Baratta, G. (2005a), "La cupa nell'ambito femminile: dalla caupona al loculus?”, in, F. Cenerini, A. Buonopane (eds.), Donna e vita cittadina nella documentazione epigrafica, 95-108.

Baratta, G. (2005b), Römische Kelteranlagen auf der italienischen Halbinsel. Ein Überblick über die schriftlichen, bildlichen und archäologischen Quellen (200 v.Chr. - 400. n.Chr.) (Cornucopia, 11), Murcia.

Baratta, G. (2005c), “Appunti sulle variabili e costanti dell' interpretatio religiosa nell'occidente romano, in F. de Oliveira, (ed.), Génese e consolidação da Ideia de Europa, vol.III, O Mundo Romano, Coimbra, 123-134

Baratta, G. (2006a), "Alcune osservazioni sulla genesi e la diffusione delle cupae", in Atti del XVI Convegno internazionale de L'Africa Romana (Rabat, 15-19 dicembre 2004), Roma, 355-368.

Baratta, G. (2006b), "Nuovi dati sull'iconografia delle mandorle nei sarcofagi strigilati. Un primo approccio ad un corpus", Annali della Facoltà di Lettere e Filosofia dell'Università di Macerata 26: 65-120.

Baratta, G. (2007), "La mandorla centrale dei sarcofagi strigilati. Un campo iconografico ed i suoi simboli", in F. Hoelscher, T. Hoelscher (eds.), Römische Bilderwelten. Von der Wirklichkeit zum Bild und zurück. Kolloquium der Gerda Henkel Stiftung am Deutschen Archäologischen Institut Rom, Heidelberg, 191-215.

Baron, H. (1938), "Cicero and the Roman civic spirit in the Middle Ages and the Early Renaissance", Bulletin of the John Rylands Library 22: 84-89.

Baron, H. (1970), La crisi del primo Rinascimento italiano, Firenze.

Barresi, P. (2007), "Il sofista Flavio Damiano di Efeso e la costruzione di termeginnasi nell'Asia Minore romana di età imperiale", in O. D. Cordovana, M. Galli, (eds.), Arte e memoria culturale nell'età della Seconda Sofistica, Catania, 137-151.

Barros, J. de (1919), Geografia d'Entre Douro e Minho e Trás-os-Montes, Porto. 
Barros, J. de (1937), Panegíricos - Panegírico de D. João III e da Infanta D. Maria, Texto restituído, prefácio e notas por M. Rodrigues Lapa, Lisboa.

Bassignano, M.S. (1974), I faminato nelle provincie romane dell'Africa, Roma.

Bastos, E. (1991), Entre o escândalo e o sucesso. A semana de 22 e o Armory show, Campinas.

Battaglia, M. (2003), "Il Vulcano dei Germani in Giulio Cesare (B.G. VI, 21, 1). Un caso di interpretatio?", Athenaeum 91: 373-401.

Beagon, M. (2005), The Elder Pliny on the Human Animal: Natural History Book 7, Oxford.

Beard, M., North, J., Price, S. (1998), Religions of Rome, vol. I, A History, Cambridge.

Behr, C.A. (ed.) (1973), Aristides, vol. I, Panathenaic Oration in Defence of Oratory, London.

Behrends, M. et alii (eds.) (2000), Hygin. L'oeuvre gromatique, Luxemburg.

Bejarano Osorio, A. M. (1996), "Sepulturas de incineración en la necrópolis oriental de Mérida: las variantes de cupae monolíticas", Anas 9: 37-58.

Belmonte, J. A. (2010), "Documentación fenicio-púnica en la Península Ibérica: estado de la cuestión", in G. Carrasco y J. C. Oliva (eds.), El Mediterráneo antiguo: lenguas y escrituras, Cuenca, 159-220.

Beltrán, F. ed. (1995), Roma y el nacimiento de la cultura epigráfica en occidente, Zaragoza.

Beltrán, F. (2000), "La vida en la frontera", in F. Beltrán, M. Martín-Bueno y F. Pina, Roma en la Cuenca Media del Ebro. La romanización en Aragón, Zaragoza.

Beltrán, F. (2002), "Identidad cívica y adhesión al príncipe en las emisiones municipales hispanas", in F. Marco, F. Pina y J. Remesal (eds.), Religión y propaganda politica en el mundo romano, Barcelona, 159-187.

Beltrán, F. (2004), "E1 latín en la Hispania romana: una perspectiva histórica", in R. Cano (ed.), Historia de la lengua española, Barcelona, 83-106.

Beltrán, F. (2004a), "Nos Celtis genitos et ex Hiberis. Apuntes sobre las identidades colectivas en Celtiberia", in G. Cruz Andreotti y B. Mora Serrano (eds.), Identidades étnicas - Identidades políticas en el mundo prerromano hispano, Kronion 1, Málaga, 87-145.

Beltrán, F. (2004b), “De nuevo sobre la tésera Froehner", Palaeohispanica 4: 4565.

Beltrán, F. (2004c), "Imagen y escritura en la moneda hispánica", in F. Chaves y F. J. García (eds.), Moneta qua scripta. La moneda como soporte de la escritura. Actas del III Encuentro Peninsular de Numismática Antigua, Anejos de AEspA 33: 125-139. 
Beltrán, F. (2004d), "Libertos y cultura epigráfica en la Hispania republicana", in F. Marco, F. Pina y J. Remesal (eds.), Vivir en tierra extraña: emigración e integración cultural en el mundo antiguo, Barcelona, 151-175.

Beltrán, F. (2005), "Cultura escrita, epigrafía y ciudad en el ámbito paleohispánico", Palaeohispanica 5: 21-56.

Beltrán, F. (2006), "Hispania y el Mediterráneo en los siglos II y I a. E.: diversidad cultural y movilidad social", in F. de Oliveira, P. Thiercy, R. Vilaça (eds.), O mar greco-latino, Coimbra, 223-240.

Beltrán, F. (2009), "Vltra eos palos. Una nueva lectura de la línea 7 de la Tabula Contrebiensis", in Espacios, usos y formas de la epigrafía hispana en épocas antigua y tardoantigua. Homenaje al Dr. Armin U. Stylow, Anejos de AEspA 48: 33-42.

Beltrán, F. (2011), "Lengua e identidad en la Hispania romana”, Palaeohispanica 11:19-59.

Beltrán, F. (2011a), “Firmas de artesano o sedes de asociaciones comerciales? A propósito de los epígrafes musivos de Caminreal (E.7.1), Andelo (K.28.1) y E1 Burgo de Ebro (HEp 11, 2001, 621 = AE 2001, 1237)", in E. Luján y J. M. García Alonso (eds.), A Greek man in the Iberian street. Papers in Linguistics and Epigraphy in honour of Javier de Hoz. Innsbrucker Beiträge zur Sprachwissenschaft 140, Innsbruck, 139-147.

Beltrán, F. (2011b), “Les colonies latines d'Hispanie (IIe siècle av. E.): émigration italique et intégration politique", in N. Barrandon y F. Kirbihler (eds.), Les gouverneurs et les provinciaux sous la République romaine, Rennes, 131-144.

Beltrán, F. (2012), "Roma y la epigrafía ibérica sobre piedra del nordeste peninsular", Palaeohispanica 12: 9-30.

Beltrán, F. (inédito), "Diversidad cultural y epigrafía: el ejemplo de Hispania", XII Congressus Internationalis epigraphiae Graecae et Latinae, Barcelona septiembre de 2002.

Beltrán, F., Estarán, M. J. (2011), “Comunicación epigráfica e inscripciones bilingües en la Península Ibérica”, in C. Ruiz Darasse y E. Luján (eds.), Contacts lingüistiques dans l'Occident méditerranéen antique. Collection de la Casa de Velázquez (126), Madrid, 9-25.

Beltrán, F., Velaza, J. (2009), "De etnias y monedas: las "cecas vasconas", una revisión crítica", in J. Andreu (ed.), Los vascones de las fuentes antiguas: en torno a una etnia de la antigüedad peninsular, Barcelona, 99-126.

Beltrán, F., Arasa, F. (1979-1980), "Los itineraria privata en la epigrafía latina”, Historia Antiqua, 9-10: 7-29.

Beltrán, F., Jordán, C., Marco, F. (2005), "Novedades epigráficas en Peñalba de Villastar (Teruel)", Palaeohispanica 5: 911-956.

Bentley, J. H. (1978), Politics and culture in Renaissance Naples, Princeton. 
Berciu, I.,Wolski, W. (1970), "Un nouveau type de tombe mise au jour à Apulum et le problème des sarcophages à voûte de l'Empire romain”, Latomus 29: 919-965.

Bergmann, M. (1998), Die Strablen der Herrscher. Theomorphes und politische Symbolik im Hellenismus und in der römischen Kaiserzeit, Mainz.

Berruti, V., Magistà, A. (eds.) (2009), L'automobile. Marche e modelli dalle origini a oggi, vol. 6, Lancia, Roma.

Besnier M., Chapot, V. (1913), "Via”, Dictionnaire des Antiquités Grecques et Romaines, 5, Paris, 777-817.

Bettini, C. (2008), “Tre Valascos nell'Italia del quatrocento: Meser Valasco di Vespasiano da Bisticci, Petrus Vallascis di Cataldo Siculo e Vasco Fernandes de Lucena", Humanitas 60: 205-226.

Bettini, M., Boldrini, M., Calabrese, O., Piccinni, G. (eds.) (2010), Miti di città, Siena.

Binsfeld, W. (1979), "Zu treverischen Kultdenkmälern”, in Festschrift 100 Jahre Rheinisches Landesmuseum Trier. Beiträge zur Archäologie und Kunst des Trierer Landes, Mainz, 263-269.

Blackman, D. (1969), "The Athenian Navy and Allied Naval Contributions in the Pentecontaetia", GRBS 10: 179-216.

Blanco Freijeiro, A. (1977), El puente de Alcántara en su contexto historico, Madrid.

Boardman, J. (1986), I Greci sui Mari. Traffici e Colonie, Trad. ital., Firenze, Giunti.

Boffo, L. (1975), "Cimone e gli alleatidi Atene”, RIL 109: 442-50.

Bol, R. (1984). Das Statuen programm des Herodes-Atticus-Nymphäums, Berlin.

Bona, G. (ed.) (1988), Pindaro. I peani, Cuneo.

Bonfante, G., Bonfante, L. (2002), The Etruscan language. An introduction. Revised edition, Manchester and New York.

Bonneville, J.-N. (1981), "Les cupae de Barcelone: les origines du type monumental", $M C V 17$ : 5-38.

Bontems, C. (1965), Le prince dans la France des XVIe e XVIIe siècles, Paris.

Bordenache, G. (1960), "Antichità greche e romane nel nuovo Museo di Mangalia”, Dacia N. S. 4: 489-509.

Bordenache, G. (1961), "Histria alla luce del suo materiale scultureo”, Dacia N. S., 185-211.fig. 16.

Bordenache, G. (1969), Sculture greche e romane del Museo Nazionale di Antichità di Bucarest I. Statue e rilievi di culto, elementi architectonici e decorativi, Bukarest.

Boschung, D. (1993a), Die Bildnisse des Augustus, Berlin. 
Boschung, D. (1993b), “Die Bildungstypen der julisch-claudischen Kaiserfamilie: ein kritischer Forschungsbericht", JRA 6: 39-79

Boschung, D. (2002), Gens Augusta. Untersuchungen zu Aufstellung, Wirkung und Bedeutung der Statuengruppen des julisch-claudischen Kaiserbauses, Mainz.

Boucher, S. (1987), "Limage et les fonctions du dieu Sucellus", Caesarodunum 23: 77-85.

Boulanger, A. (1923), Aelius Aristide et la sophistique dans la province d'Asie au II siècle de notre ère, Paris.

Bowersock, G.W. (1969), Greek Sophists in the Roman Empire, Oxford.

Braancamp Freire A. (ed.) (1916), Notícias da Vida de André de Resende pelo Beneficiado Francisco Leitão Ferreira, Lisboa.

Bracco, V. (1985), "Il tabellarius di Polla", Epigraphica 47: 93-97.

Brandão, M. (1937), Documentos de D. João III, I, Coimbra.

Brandt, H. (1998), Geschichte der römischer Kaiserzeit. Von Diokletian und Konstantin bis zum Ende der konstantinische Dynastie (264-363), Berlin.

Briant, P. (2002), From Cyrus to Alexander. A History of the Persian Empire, Winona Lake.

Brown, B.R. (1957), Ptolemaic Paintings and Mosaics and the Alexandrian style, Cambridge.

Brown, T. S. (1946), "Euhemerus and the Historians", HThR 39: 259-274.

Brun, J.-P. (1986), L'oléiculture antique en Provence. Les huiliers du departement du Var (RANArb suppl. 15), Paris.

Brun, J.-P. (2003), Le vin et l'huile dans la Méditerranée antique. Viticulture, oléiculture et procédés de transformation, Paris.

Brun, J.-P. (2004), Archéologie du vin et de l'huile dans l'empire romain, Paris.

Brun, J.-P. (2005), Archéologie du vin et d'buile en Gaule romaine, Paris.

Bruneau, P. (1985), "Deliaca. Iconographie. L'image de Delos personifiée e pyxides de Spina”, BCH 109: 551-556.

Búa, C. (1997), "Dialectos indoeuropeos na franxa ocidental hispânica”, in G. Pereira (ed.), Galicia fai dous mil anos. O feito diferencial galego, volumen I. Historia, Santiago de Compostela, 51-99.

Buck, R. J. (1979), A History of Boeotia, Edmonton.

Bulloch, A. W (1985), Callimachus. The Fifth Hymn, Cambridge.

Bulloch, A. W (2010), "Hymns and Encomia", in J. J Clauss and M. Cuypers (eds.), A Companion to Hellenistic Literature, Malden/Oxford, 166-180.

Burazacchini, G. (ed.) (2005), Troia tra realtà e legenda, Parma.

Burckhardt J. (1949), The Age of Constantine the Great, Berkeley. 
Burke, P. (1987 3a ed.), The italian Renaissance culture and society in Italy, Cambridge.

Burkert, W. (1991), Mito e Mitologia, Ed. 70, Lisboa.

Burkhalter-Arce, F. (2002), "Le tarif de Coptos". La douane de Coptos, les fermiers de l'apostolion et le préfet du desert de Bérénice”, Topoi Supp. 3: 199-233.

Burnett, A. P. (2005), Pindar's Songs for Young Athletes of Aigina, Oxford.

Bury, J. B., Cook, S. A., Adcock ,F. E. (eds.), The Cambridge Ancient History, Vol. 4, Cambridge.

Butcher, K. (2003), Roman Syria and the Near East, London.

Buxton, R. (ed.) (1999), From Myth to Reason? Studies in the Development of Greek Thought, Oxford.

Caccamo Caltabiano, M. (2003), "Messana/Tyche sulle monete della città dello stretto", in Archeologia del Mediterraneo. Studi in onore di Ernesto De Miro, Roma, 139-149.

Cadotte, A. (2007), La romanisation des dieux. L'interpretatio romana en Afrique du Nord sous le Haut-Empire (Religions in the Graeco-Roman world 158), Leiden.

Caiado, H. (1745), Eclogae et Sylvae et Epigrammata, in Pe. A. dos Reis, Corpus illustrium poetarum Lusitanorum, qui latine scripserunt, Lisboa.

Cairns, D. L. (2010), Bacchylides: five epinician odes (3, 5, 9, 11, 13), Cambridge.

Camia, F. (2011), Theoi sebastoi. Il culto degli imperatori romani in Grecia (provincia Achaia) nel secondo secolo D.C., Athinai.

Caldera de Castro, M. D. P. (1978), "Una sepultura de cupa hallada en Mérida. (Consideraciones acerca de estos monumentos funerarios)", Habis 9: 455-463.

Calderón Dorda, E., De Lazzer, A., Pellizer, E., (eds.) (2003), Corpus Plutarchi Moralium, Naples.

Calvino, I. (1996), "Diario americano, 1959-1966”, in Eremita a Parigi. Pagine autobiografiche, Milano, 20-124.

Calvino, I. (1996a), Città invisibili, Milano.

Camargos, M. (2001), Villa Kyrial: crônica da Belle Époque paulistana, São Paulo.

Cameron A. (1993), The later Roman empire: AD 284-430, Cambridge.

Cantemir, D. (2006), The Salvation of the Wise Man and the Ruin of the Sinful World [...], ed., trans., notes, indices Ioana Feodorov, Editura Academiei, Bucuresti.

Cantemirius, D. (1973), Descriptio antiqui et hodierni status Moldaviae/ Dimitrie Cantemir, Descrierea Moldovei, trans. Gh. Gutu, introd. Maria Holban, hist. com. N. Stoicescu, cartographical study Vintilă Mihailescu, index Ioana Constantinescu, note D. M. Pippidi, Bucuresti. 
Bibliografia

Cantemirius, D. (2006), Descriptio antiqui et hodierni status Moldaviae/ Dimitrie Cantemir, Principele Moldovei, Descrierea stării de odinioară şi de astăzi a Moldovei, ed., trans. Dan Slusanschi, Bucuresti.

Cantineau, J. (1935), Grammaire du palmyrénien épigraphique, Le Caire.

Carcopino, J.(s/d), A vida quotidiana em Roma no apogeu do Império (trad A. J. Saraiva), Lisboa.

Cardim Ribeiro, J. (2002), "Soli Aeterno Lunae. O santuário", Religiões da Lusitânia. Loquuntur Saxa, Lisboa, 235-239.

Cardim Ribeiro, J. (2005), "O deus sanctus Endovellicus durante a romanidade. Uma interpretatio local de Faunus-Silvanus?”, Paleohispanica 5: 721-766.

Carlier p. (1990), Démosthène, Paris.

Carneiro, A., d'Encarnação, J., de Oliveira, J., Teixeira, Cl. (2008), "Uma iscrição votiva em lengua lusitana”, Palaeobispanica 8: 167-178.

Caro, A. (2009), “Una fase decisiva en la evolución de la publicidad: la transición del producto a la marca", Pensar la publicidad, III, 2: 109-114.

Caro, A. (2010), Comprender la publicidad, Barcelona.

Cartledge, P. (2009), Ancient Greek Political Thought in Practice, Cambridge.

Carvalho, J. de (1947-1948), Estudos sobre a cultura portuguesa do século XVI, 2 vols. Coimbra.

Carvalho, J. de (1949), Estudos sobre a cultura portuguesa do século XV, Coimbra.

Cascudo, L. C. (1974), Prelúdio e fuga do real, Natal.

Cascudo, L. C. (1983), Civilização e Cultura, pesquisas e notas de etnografia geral, Belo Horizonte.

Cascudo, L. C. (1983, 2ª ed.), Anúbis e outros ensaios. Mitologia e folclore, Rio de Janeiro, Natal.

Cascudo, L. C. (1987), História dos nossos gestos, Belo Horizonte, São Paulo.

Cascudo, L.C. (1966), "História de um livro perdido", Arquivos do Instituto de Antropologia "Câmara Cascudo" 2.1-2: 5-19.

Castelli, E. (1951) (ed.), Umanesimo e Scienza politica. Atti del congresso Internazionale di Studi Umanistici, Roma-Firenze, 1949, Milano.

Castillo, C. (1998), "Los flamines provinciales de la Bética", REA 100: 437-460

Cawkwell, G. (2005), The Greek Wars. The Failure of Persia, Oxford.

Cesarano, M. (2015), In honorem domus divinae. Introduzione allo studio dei cicli statuari giulio-claudii a Roma e in Occidente, Roma.

Clauss, M. (1979), Kaiser und Gott: Herrscherkult im romischen Reich, Berlin.

Chamie, M. (2009), Paulicéia dilacerada, Ribeirão Preto.

Chaniotis, A. (2009), "The Dynamics of Rituals in the Roman Empire", in O. 
Hekster, S. Schmidt-Hofner, Chr. Witschel (eds.), Ritual Dynamics and Religious Change in the Roman Empire. Proceedings of the Eight Workshop of International Network Impact of Empire, Leiden, Boston, 3-29

Charles-Picard, G., Rougé, J. (1969), Textes et documents relatifs à la vie economique et sociale dans l'Empire romain, Paris.

Chassaing, M. (1961), "Les barillets frontiniens“, RAE 12: 7-33, 89-106.

Chelotti, M. (2003), Regio II, Apulia et Calabria, Venusia (Supplementa Italica 20), Roma.

Cherry, D. (1998), Frontier and Society in Roman North Africa, Oxford.

Chevallier, R. (1972), Les voies romaines, Paris.

Chevallier, R. (1988), Voyages et déplacements dans l'Empire romain, Paris.

Chiarelli, G. (1932), 'Il 'De regno' di Francesco Patrizi', Rivista internazionale di filsosofia del diritto, Anno XII. (Nov-Dec.): 716-738.

Cistercienses (Os). Documentos primitivos. Texto latino e tradução brasileira. (1997) Introdução e bibliografia Irmão François de Place, Tradução de Irineu Guimarães, Musa, S. Paulo; Lúmen Christi, Rio de Janeiro 1997.

Clauss, J., Cuypers, M. (eds.) (2010), A Companion to Hellenistic Literature, Chichester, West Sussex.

Clavel-Lévêque, M. et alii (eds.) (1993), Siculus Flaccus. Les conditions des terres, Nápoles.

Clavel-Lévêque, M. et alii (eds.) (1996), Hygin l'arpenteur. L' établissement des limites, Nápoles.

Clayton, P.A. (1989), Le sette Meraviglie del mondo, Torino. (The Seven Wonders of the Ancient World, London, 1988).

Cogitore, I. (1996), “Séries de dédicaces italiennes à la dynastie julio-claudienne”, MEFRA 104 : 817-870.

Colasso, F. (1951), "Umanesimo giuridico", in E. Castelli (ed.), Umanesimo e Scienza politica (Atti dei Congresso Internazionale di Studi Umanistici, Roma-Firenze, 1949), Milano, 57-58.

Colecchia, A., Bertolani, G. B., Marcante, A. et alii (2004), L'Alto Garda occidentale dalla preistoria al postmedioevo. Archeologia, storia del popolamento e trasformazione del paesaggio (Documenti di archeologia, 36), Mantova.

Colonna, G. (1980), "Virgilio, Cortona e la leggenda etrusca di Dardano", Archeologia Classica 32: 1-15.

Conger, G. P. (1952), "Did India influence Early Greek Philosophies?", Philosophy East and West 2.2: 102-128.

Conti, S. (1997), "Dinastia giulio-claudia a Roselle: una serie di dediche imperiali in Etruria”, Ann. Fac. Lett. e Filos. Univ. Siena 18: 101-127. 
Conti, S. (1998), Rusellae, Suppl. It. n. s. 16, Roma.

Cook, J. M. (1971), Os Gregos na Iónia e no Oriente, Lisboa.

Cooley, A. E. (ed.) (2002), Becoming Roman, Writing Latin? Literacy and Epigraphy in the Roman West. JRA Suppl. Ser. 48, Portsmouth.

Cooley, A. E. (2002), "The survival of Oscan in Roman Pompeii”, in E. A. Cooley (ed.), Becoming Roman, Writing Latin? : Literacy and Epigraphy in the Roman West, JRA Suppl. Ser. 48: 77-86.

Cordovana, O. D., Galli, M. (eds.) (2007), Arte e memoria culturale nell'età della Seconda Sofistica, Catania.

Corell, J. (1989), “Notas sobre epigrafía romana del País Valenciano”, APL 19: 271-281.

Costa, A. D. S. (1969), Estudantes portugueses na reitoria do Colégio de S. Clemente de Bolonha na primeira metade do século XV, Lisboa.

Costa, A. D. S. (1990), Portugueses no Colégio de S. Clemente e Universidade de Bolonha durante o século $X V$, vol. I, Bolonia.

Coulanges, F. de. (1971, 10ª ed.), A cidade antiga, Trad. e glossário de Fernando de Aguiar, Livraria Clássica Editora, Lisboa.

Crawford, M. H., Reynolds, J. M. (1979), “The Aezani copy of the Prices Edict”, Zeitschrift für Papyrologie und Epigraphik 34: 163-210.

Crystal, D. (2000), Language death, Cambridge.

Curado, F. P. (1985), "Inscrição rupestre de Freixo de Numão”, Ficheiro Epigráfico 11: no48.

David, B., Thomas J. (eds.) (2008), Handbook of landscape archaeology (World archaeological congress research handbooks in archaeology, 1), Walnut Creek.

Davie, J. N. (1982), "Theseus the king in fifth-century Athens", GE'R 29.1: 2534.

DCPH = M. P. García-Bellido y C. Blázquez (2001), Diccionario de cecas y pueblos hispánicos, Madrid.

De Bernardo Stempel, P. (2008), "More names, fewer deities. Complex theonymic formulas and the three types of interpretation", in Divindades indígenas em análise. Divinités pré-romaines. Bilan et perspectives d'une recherche. Actas do VII workshop FERCAN, Cascais, 25-27.5.2006, Coimbra, 65-73.

De Hoz, J. (2001), "La lengua de los íberos y los documentos epigráficos en la comarca de Requena-Utiel”, in A. J. Lorrio (ed.), Los íberos en la comarca de Requena-Utiel (Valencia), Madrid, 49-62.

De Hoz, J. (2010), Historia lingüistica de la Península Ibérica en la Antigüedad. I. Preliminares y mundo meridional prerromano, Madrid. 
De Hoz, M. P. (1997), “Epigrafía griega en Hispania”, Epigraphica 59: 29-93.

De Labriolle, P. (1934), La reaction païenne, Paris.

De Martino, D. (2010), "Spot, etica e letteratura", La nuova ricerca. Pubblicazione annuale del Dipartimento di Linguistica, Letteratura e Filologia moderna dell'Università degli studi di Bari, anno XIX. 19, 117-128.

De Martino, D. (2010 bis), "Automobili da mito", in F. De Martino (ed.), Antichità Ẽ pubblicità, Bari, 443-522.

De Martino, D. (2011), Io sono Giulietta. Letterature E' miti nella pubblicità di auto, Bari.

De Martino, D. (2012), "Una forma de subversión del mito literario: de la novela a la publicidad", in J. M. Losada Goya, M. Guirao Ochoa (eds.), Myth and Subversion in the Contemporary Novel, Cambridge, 421-436.

De Martino, D. (2013), Dante E̋ la pubblicità, Bari.

De Martino, F., Vox, O. (1996) (eds.), Lirica greca, vol. 3, Bari.

De Ruyt, Cl. (1983), Macellum. Marché alimentaire des romains, Louvain-laNeuve.

De Santerre, H. H. (1976), "Athènes, Délos et Delphes d'après une peinture de vase à figure rouges du V siècle avant J.-C.”, BCH 100: 291-298.

De Vos, M., Andreoli, M., Attoui, R. et alii (2007), "Cilicia campestris orientale. Leconomia rurale e la trasformazione del paesaggio intorno al Karasis", in Geografia e viaggi nell'antichità. Atti del convegno internazionale di studi (Certosa di Pontognano, 9-10 ottobre 2005), Siena, 13-39.

Degl'Innocenti Pierini, R. (2012), "Le città personificate nella Roma repubblicana: fenomenologia di un motivo letterario tra retorica e poesia", in G. Moretti, A. Bonandini (eds.), Persona ficta. La personificazione allegorica nella cultura antica, fra letteratura, retorica e iconografia, Trento, 215-247.

Desbat, A. (1991), "Un bouchon de bois du Ier s. aprés J.-C. recueilli dans la Saône à Lyon et la question du tonneau à 1'époque romaine", Gallia 48: 319-336.

Dias, P. B. (2011 2a ed.), “Notas introdutórias”, in J. G Freire, A versãolatina por Pascásio de Dume dos Apophtegmata Patrum, Coimbra, 1-34.

Dias, P. B. (2012), “Cristianismo e responsabilidade cristã na queda de Roma”, in F. Oliveira et alli (coords.), A queda de Roma e o alvorecer da Europa, Coimbra, 43-67.

Dias P. B. (2013), "O legado de Constantino na identidade da Europa cristã: dois casos de estudo", in M. C. Pimentel e P. Farmhouse Alberto (orgs.), Vir bonus peritissimus aeque. Estudos de homenagem a Arnaldo do Espirito Santo, Lisboa, 455-463 
Díaz, B. (2008), Epigrafía latina republicana de Hispania, Barcelona.

Dittenberger, W., Purgold, K. (1896), Inschriften von Olympia, Berlin.

Dixon, R. M. W. (1997), The rise and fall of languages, Cambridge.

Domăneanțu, C. (1993), "Un sanctuaire hellénistique du site de Nuntaşi II (comm. d'Istria, dep. De Constanța)”, Dacia 37: 59-78.

Dörfler, W., Evans, A., Löhr, H. (1998), “Trier, Walramsneustrasse. Untersuchungen zum römerzeitlichen Landschaftswandel im Hunsrück-Eifel-Raum an einem Beispiel aus der Trierer Talweite“, in Studien zur Archäologie der Kelten, Römer und Germanen in Mittel- und Westeuropa. Alfred Haffner zum 60. Geburtstag gewidmet, Rahden, 119152.

Dubuisson, M. (1981), "Utraque lengua”, L'Antiquité Classique 50: 274-286.

Dubuisson, M. (1982), "Y a-t-il une politique linguistique romaine?”, Ktéma 7: 197-210.

Duchesne, L. (1887), "Le concile d'Elvire et les flamines chrétiens", Mélanges Renier, Paris, 159-174.

Dunkle, J. R. (1969), “The Aegeus episode and the theme of Euripides' Medea", TAPhA 100: 97-107.

Durán Fuentes, M. (2005), La construcción de puentes romanos en Hispania, Santiago de Compostela.

Eck, W. (2006), "Herrschaft und Kommunikation in antiken Gesellschaften. Das Beispiel Rom", in U. Peter, S. J. Seidlmayer (eds.), Mediengesellschaft Antike? Information und Kommunikation vom Alten Ägypten bis Byzanz, Berlin, 11-33.

Eco, U. (2013), Storia delle terre e dei luoghi leggendari, Milano.

Eddy, S.K. (1968), “Four Hundred Sixty Talents Once More”, CP 63: 184-95.

Edmonson, J. (1997), “Two dedications to Divus Augustus and Diva Augusta from Augusta Emerita and the early development of the imperial cult in Lusitania", MM 38: 89-105.

Edmondson, J. (2002), "Writing latin in the province of Lusitania", in A. E. Cooley (ed.), Becoming Roman, Writing Latin? Literary and Epigraphy in the Roman West, JRA Suppl. Ser. 48: 41-60.

Ehrenberg, V. (1973, 2a ed.), From Solon to Sócrates, Londres.

Ehrenberg, V. (1976), L'État grec, Paris.

Ehrhardt, N. (1988), Milet und seine Koloniei. Vergleichende Untersuchung der kultischen und politischen Einrichtungen, ed. a II-a, Frankfurt, Main-Bern, New York, Paris.

Elliger, W. (1975), Die Darstellung der Landschaft in der griechischen Dichtung, Berlin, New York. 
Elliott, Th. (1990), “The Language of Constantinian Propaganda”, TAPhA 120: 349-353.

Encarnação, J. d' (1984), Inscrições romanas do Conventus Pacensis, Coimbra.

Erasmo, D. (1703), Opera omnia (in decem tomos distincta), Recognovit Joannes Clericus, Leiden.

Erodoto (1988), Le Storie. Libro I. La Lidia ela Persia. Acura di David Astheri, Milano.

Erskine, A. (ed.) (2003), A Companion to the Hellenistic World, Oxford.

Espérandieu, E. (1907-1981), Recueil général des bas-reliefs, statues et bustes de la Gaule romaine, Paris.

Estarán, M. J. (2012), “Las estampillas ibérico-latinas K.5.4”, Palaeohispanica 12: $73-90$

ET = Rix, H. (1991), Etruskische Texte, Tübingen.

Étienne, R. (1958), Le culte impérial dans la Péninsule ibérique d’Auguste à Diocletien, Paris.

Étienne, R. (1973), "Les syncrétismes dans la Péninsule Ibérique à l'époque impériale", in Les syncrétismes dans les religions grecque et romaine, Paris, 153-163.

Étienne, R., Fabre, G.; Lévêque, P. et M. (1976), Fouilles de Conimbriga, vol. II, Épigraphie et Sculpture, Paris.

Étienne, R., Fabre, G., Le Roux, P., Tranoy, A. (1976), "Les dimensions sociales de la romanisation dans la Péninsule Ibérique des origines à la fin de l'Empire", in D. M. Pippidi (ed.), Assimilation et résistance à la culture gréco-romaine dans le monde ancien. Travaux du VI Congrès International d'Études Classiques, Bucureşti, Paris, 95-107.

Étienne, R., Mayet, F. (2000), Le vin hispanique, Paris.

Evans, J. A. S. (1981), "Notes on the debate of the Persian Grandees in Herodotus 3, 80-82”, QUCC 36: 79-84.

Evers, C. (1994), Les portraits d'Hadrien. Typologie et ateliers, Bruxelles.

Ewald, C., Norena, C. F. (eds.) (2010), The Emperor and Rome: Space, Representation, Ritual, Cambridge.

Fabre, G., Mayer, M., Rodà, I. (1991), Inscriptions romaines de Catalogne, III, Paris.

Fayer, C. (1976), Il culto della dea Roma. Origine e diffusione nell'Impero, Pescara.

Fearn, D. (2007), Bacchylides. Politics, performance, poetic tradition, Oxford.

Fernandes, L., Carvalho, P., Figueira, N. (2009), "Divindades indígenas numa ara inédita de Viseu", Palaeohispanica 9: 143-155.

Fernández Gallardo, L. (2002), Alonso de Cartagena. Una biografía politica en la Castilla del siglo XV, Valladolid. 
Fernández Gallardo, L. (2008), “Alonso de Cartagena y el Humanismo”, La Corónica 37.1: 175- 215.

Ferraz, C. (2002), "Conjunto de oito aras provenientes do Lararium de Centum Celas", in V. L. Raposo, J. R. Ferreira (Coords.), Religióes da Lusitânia. Loquuntur Saxa, Lisboa, 467-469.

Ferreira, J. R. (1988), "Grécia e Roma na Revolução Francesa”, Revista de História das Ideias 10: 203-234.

Ferreira, J. R. (1990), A democracia na Grécia Antiga, Coimbra.

Ferreira, J. R. (1990a), Participação e poder na democracia grega, Coimbra.

Ferreira, J. R. (1993), Hélade e Helenos I - Génese e Evolução de um Conceito, Coimbra.

Ferreira, J. R. (2004 2a ed.), A Grécia Antiga. Sociedade e Politica, Lisboa.

Ferreira, J. R., (1991), "Presença da Grécia e de Roma na Revolução Francesa", in Actas do colóquio A Recepção da Revolução Francesa em Portugal e no Brasil, Porto, vol. I, 75-96.

Ferri, S. (1976), "Luci e ombre sulla interpretatio romana", in Convegno internazionale "Renania romana" Roma 14-16 aprile 1975, Roma, 125133.

Ferrill, A. (1978), "Herodotus on tyranny", Historia 27.3: 385-398.

Figueira, T. J. (1998), The Power of Money: Coinage and Politics in the Athenian Empire, Philadelphia.

Figueira, T. J. (2003), "Economic Integration and Monetary Consolidation in the Athenian Arkhê", in G. Urso (ed.), Moneta, Mercanti, Banchieri. I precedenti greci e romani dell'Euro, Pisa, 71-92.

Figueira, T. J. (2005), "The Imperial Commercial Tax and the Finances of the Athenian Hegemony”, Incidenza dell'antico 3: 83-133.

Figueira, T. J. (2006), "Reconsidering the Athenian Coinage Decree", AIIN 52: 9-44.

Figueira, T. J. (2011), "The Athenian Naukraroi and Archaic Naval Warfare”, Cadmo. Revista de História Antiga 21: 183-210.

Figueira, T. J. (forthcoming[a]), "Archaic Naval Warfare”, in N. Birgalias (ed.), Great is the Power of the Sea: The Power of Sea and Sea Powers in the Greek world of the Archaic and Classical Periods, Athens.

Figueira, T. J. (forthcoming[b]), "The Aristeidian Tribute on the Peace of Nikias", in S. Jensen, T. Figueira (eds.), Athenian Hegemonic Finances, Swansea.

Figueira, T. J. (forthcoming[c]), "Community Wealth and Military Might in Periclean Athens", in A.L. Pierris (ed.), Mind, Might, Money: The Secular Triad in Classical Athens, Patras. 
Figueira, T. J. (forthcoming[d]), “Aigina: Island as Paradigm”, in A. Powell and K. Meidani (eds.), The Eyesore of Aigina: Anti-Athenian Attitudes in Greek, Hellenistic and Roman History, Swansea.

Figueiredo, R., Lamounier, B. (1996), As cidades que dão certo, Brasília.

Finley, M.I. (1966), The Ancient Greeks. An introduction to their life and thought, Londres. Trad. port.: Os Gregos Antigos (Lisboa, 2a ed. 1988).

Finley, M. I. (1973, 2a ed.), Democracy, ancient and modern, London.

Finley, M.I. (1973a), The ancient economy, London.

Finley, M.I. (1982), Authority and legitimacy in the classical city-state, Kobenhavn.

Fishwick, D. (1970), "Flamen Augustorum”, HSCPh 74: 299-312.

Fishwick, D. (1982), "The altar of Augustus and the municipal cult of Tarraco", MM 23: 222-233

Fishwick, D. (2002), The Imperial Cult in the Latin West, 3/2, Provincial Cult I The Provincial Priesthood, Leiden.

Fishwick, D. (2005), The Imperial Cult in the Latin West. Studies in the Ruler Cult of the Western Provinces of the Roman Empire, Leiden, Boston.

Fitton, J. W. (1961), "The Suppliant Women and the Herakleidai of Euripides", Hermes 89.4: 430-461.

Flower, M. F. (2007), "Appendix R: The Size of Xerxes Expeditionary Force," in Robert B. Strassler (ed.), The Landmark Herodotus: The Histories, New York, 819-23.

Fonseca, L. A. (1982), O Condestável D. Pedro de Portugal, Porto.

Fontanella, F. (2008), "The Encomium on Rome as a response to Polybius' doubts about the Roman Empire", Columbia Studies in the Classical Tradition 33: 203-216.

Forni, G. (1973), "El culto de Augusto en el compromiso oficial y en el sentimiento oriental", BSAA 39: 105-113.

Forni, G. (1994), Scritti vari di Storia, Epigraphia e antichità romane, Roma.

Franck, A. D. (1864), Réformateurs et publicistes de l'Europe: Moyen ÂgeRenaissance, Paris.

French, A. (1972), "The Tribute of the Allies", Historia 21: 3-20.

Fuentes, M. J. (1986), Corpus de las inscripciones fenicias, púnicas y neopúnicas de Hispania, Barcelona.

Gabba, S., Drioton, É. (1954), Peintures à fresques et scènes peintes a Ermoupolis Ouvest (Touna el-Gevel), Le Caire.

Gaffiot, F. (s/d), Dictionnaire latin-français, Paris.

Gagé, J. (1936), "Le templum Urbis et les origines de l'idée de Renovatio", in Mélanges Franz Cumont, Bruxelles, 151-187. 
Gagé, J. (1955), Apollon romain. Éssai sur le culte d'Apollon et le développement du "ritus Graecus" à Rome des originrs à Auguste, Paris.

Gagé, J. (1968), "Basiléia”. Les Césars, les rois d'Orient et les "mages", Paris.

Gagé, J. (1974), "Le solemne Urbis du 21 avril au III" siècle ap. J.-C.: Rites positives et speculations séculaires", Mélanges d'histoire de religions offerts à Henri-Charles Puech, Paris, 225-241.

García Bellido, M. P. (1993), "Sobre el culto de Volcanus y Sucellus en Hispania. Testimonios numismáticos", in F. Burkhater, J. Arce (eds.), Bronces y religión romana. Actas del XI Congreso internacional de bronces antiguos, Madrid mayo - junio 1990, Madrid, 161-170.

García Iglésias, L. (1976), "Autenticidad de la inscripción de municipios que sufragaron el puente de Alcántara”, Revista de Estudios Extremeños 32.2: 263-276.

García Jurado, F. (2007), Aulo Gelio, Noches Aticas. Antología, Madrid.

García Romero, F. (2002), "Pervivencia de Penélope”, in C. Morenilla Talens, F. De Martino (eds.), El perfil de les ombres, Bari, 187-204.

García Soler, M. J. (2010), "Gastronomia e pubblicità nella Grecia antica”, in F. De Martino (ed.), Antichità Ẻ pubblicità, Bari, 345-366.

Garin, E. (1955), "Ricerche sulle traduzioni di Platone nella prima metà del XV secolo", Medioevo e Rinascimento, Studi in onore di B. Nardi, Firenze.

Garin, E. (1966), Storia della filosofia italiana, Torino.

Garriguet, J. A. (2004), "Grupos estatuarios imperiales de la Bética: la evidencia escultórica y epigráfica”, in Actas de la IV reunión sobre escultura romana en Hispania, Madrid, 67-101.

Gasperini, L. (1977), “L’Augusteo di Firmo Piceno in un'epigrafe da rileggere”, AFML 10: 57-87.

Gasperini, L. (2008), "L’Augusteo di Forum Clodii”, en L. Gasperini, G. Paci, (eds.), Nuove ricerche sul culto imperiale in Italia, Tivoli, 91-134.

Gasperini, L., Paci, G. (eds.) (2008), Nuove ricerche sul culto imperiale in Italia, Tivoli.

Gaudemet J. (1947), “La législation religieuse de Constantin”, Rérue d' Histoire de l'Église de France 122: 25-61.

Genette, G. (1997), Palinsesti. La letteratura di secondo grado, Torino.

Gentili, B. (ed.) (1995), Pindaro. Le pitiche, Milano.

Ghedini, F. (2000), "Filostrato Maggiore come fonte per la conoscenza della pittura antica”, Ostraka 9.1: 75-197.

Giachero, M. (ed.) (1974), Edictum Diocletiani et Collegarum de pretiis rerum venalium in integrum restitutum e latinis gracisque fragmentis, 1-2, Génova. 
Gico, V. (1998), "Luís da Câmara Cascudo: perfil bibliográfico", in L. C. Cascudo, Ontem. (Maginaçôes e notas de um professor de provincia), Natal.

Gigli, D. (1985), Metafora e poetica in Nonno di Panopoli, Firenze.

Gilles, K. J. (1987), "Römische Glasgefäße", in AA.VV., 2000 Jahre Weinkultur an Mosel-Saar-Ruwer. Denkmäler und Zeugnisse zur Geschichte von Weinbau, Weinhandel, Weingenuß, Trier, 143-145.

Gilles, K. J. (1987b), “Trierer Weinkeramik”, in AA.VV., 2000 Jabre Weinkultur an Mosel-Saar-Ruwer. Denkmäler und Zeugnisse zur Geschichte von Weinbau, Weinhandel, Weingenuß, Trier, 132-133.

Gilles, K. J., König, M., Schumann, F. (1995), Neuere Forschungen zum römischen Weinbau an Mosel und Rhein (Schriftenreihe des Rheinischen Landesmuseums Trier, 11), Trier.

Gilson, É. (1983, 6ª ed.), Le thomisme, Paris.

Gómara, M. (2007), "Una inscripción paleohispánica sobre cerámica altoimperial en Cascante (Navarra)", Palaeohispanica 7: 263-268.

Gomes, S.A. (1998), Visitações a mosteiros cistercienses em Portugal. Séculos XVe XVI, Ministério da Cultura - IPPAR, Lisboa.

Gomes, S. A. (2000), "Revisitação a um velho tema: a fundação do Mosteiro de Alcobaça”, in Cister: Espaços Território e Paisagens. Colóquio Internacional, 16-20 Junho de 1998, Mosteiro de Alcobaça. Actas. I, Lisboa, 27-72.

Gomes, S. A. (2000), O mosteiro de Alcobaça na transição dos séculos XIV e XV: o protagonismo de D. João Dornelas, in Cister. Espaços, Territórios, Paisagens. Colóquio Internacional. 16-20 Junho 1998. Mosteiro de Alcobaça, Lisboa, 73-88.

Gomes, S. A. (2006), D. Afonso V, Círculo de Leitores-Colecção Reis de Portugal, Lisboa.

Gómez García, C. (2010), "La configuración de la ciudad de Berlin”, in J. M. Losada Goya (ed.), Mito y mundo contemporáneo. La recepción de los mitos antiguos, medievales y modernos en la literatura contemporánea, Bari , 617626.

González Rolán, T., P. Saquero Suárez-Somonte, P. (2001), “E1 Humanismo italiano en la Castilla del cuatrocientos: estudio y edición de la versión castellana y del original latino del De infelicitate principum de Poggio Bracciolini “, Cuadernos de Filología Clásica. Estudios Latinos 21: 115-150.

González Rolán, T., Moreno Hernández, A., Saquero Suárez-Somonte, P. (2000), Humanismo y teoría de la traducción en España e Italia en la primera mitad del siglo XV. Edición y estudio de la Controversia Alphonsiana (Alfonso de Cartagena vs. L. Bruni y P. Candido Decembrio), Madrid.

Gorrochategui, J. (1987), "Situación lingüística de Navarra y aledaños en la antigüedad a partir de las fuentes epigráficas", Primer Congreso General de Historia de Navarra II, Pamplona, 435-445. 
Gorrochategui, J. (2014), "Nueva inscripción funeraria celtibérica procedente de Clunia”, Palaeobispanica 14: 229-236.

Gorrochategui, J.y Vallejo, J. M. (2010), “Lengua y onomástica. Las inscripciones lusitanas", Iberografías 6: 71-80.

Gose, E. (1976), Gefäßtypen der römischen Keramik im Rheinland, Köln.

Graham, A.J. (1964), Colony and Mother City, Manchester.

Grenier, A. (1934), Manuel d'archéologie gallo-romaine 2, Les routes, Paris.

Gros, P., Marin, M., Zink, M. (eds.) (2015), Auguste, son époque et l'Augusteum de Narona. Actes du colloque organisé à l 'Académie des Inscriptions et Belles-letres le 12 décembre 2014, Paris.

Gualandi, M. L. (2001), Le fonti per la storia dell'arte - I. L'antichità classica, Roma.

Guarducci, M. (1974), Epigrafia greca, vol. III, Roma.

Guarducci, M. (1978), Epigrafia greca, vol. IV, Roma.

Guerra, A., Schatner, T. (2010), "El foro y el templo de Lancia Oppidana: nueva interpretación de Centum Celas (Belmonte)", in T. Mogale Basarrate (ed.) Ciudad y Foro en Lusitania Romana, Mérida, 333-342.

Guilaine, J. (cur.) (1991), Pour une archéologie agraire: à la croisée des sciencies de l'homme et de la nature, Paris.

Guilmartin, J. F. (2002), Galleons and Galleys, London.

Guilmartin, J. F. (2003), Gunpowder and Galleys. Changing Technology and Mediterranean Warfare at Sea in the Sixteenth Century, 2nd ed., Annapolis.

Hall, J. M. (1997), Ethnic identity in Greek Antiquity, Cambridge.

Hanell, K. (1934), Megarische Studien, Lund.

Hänlein-Schäfer, H. (1985), Veneratio Augusti. Eine Studie zu den Tempeln der ersten römischen Kaisers, München.

Hanley, R. (2000), Villages in Roman Britain, Princes Risborough.

Hansen, H. M. (1991), The Athenian Democracy in the age of Demosthenes. Structure, Principles and Ideology, Oxford.

Hardy, E. G. (1925), "The Lex Mamilia Roscia Peducaea Alliena Fabia”, The CQ 19 (3/4): 185-191.

Harris, E. (1995), Aeschines and Athenian Politics, Oxford.

Harth, H. (1984), Poggio Bracciolini, Lettere, Leo S. Olschki Editore, Florencia.

Hekster, O., Schmidt-Hofner, S., Witschel, Chr. (eds.) (2009), Ritual dynamics and Religious Change in the Roman Empire. Proceedings of the Eighth Workshop of the International Network Impact of Empire, Leiden, Boston.

Helck, W. (1971), Das Bier im alten Ägypten, Berlin. 
Hershowitz, A., (forthcoming), "Patterns in Variation in Tribute Assessment", in S. Jensen, T. Figueira (eds.), Athenian Hegemonic Finances, Classical Press of Wales, Swansea.

Herta, P. (1978), "Bibliographie zum römischer Kaiserkult (1955-1975)", ANRW II 18: 833-910.

Heubeck, A. (ed.) (1983), Omero. Odissea, Volume III (Libri IX-XII), Milano.

Heurgon, J. (1950-1951), "La syntaxe des routiers romains", Bulletin de la Société des Antiquaires de France: 145-154.

Heurgon, M. (1969), "Inscriptions étrusques de Tunisie”, CRAI, 526-551.

Heurgon, M. (1969a), “Les Dardaniens en Afrique”, REL 47: 284-294.

Higbie, C. (2007), "Hellenistic Mythographers", in R. Woodart (ed.), The Cambridge Companion to Greek Mythology, Cambridge, 237-54.

Hignett, C. (1963), Xerxes' Invasion of Greece, Oxford.

Hoffmann, C. (1991), An introduction to bilingualism, London, New York.

Hoffmann, M. (1956), 5000 Jahre Bier, Berlin.

Holban, M., Bulgaru, M. M. A., Cernovodeanu, P. (eds.) (1980-83), Calatori straini despre tarile române (Foreign Travellers about the Romanian Countries), Bucuresti, vol. VII: 1980; vol. VIII: 1983.

Homo, L. (1972), Rome impériale et l'urbanisme dans l'antiquité, Paris.

Hopkinson, N. (1984), “Callimachus' Hymn to Zeus”, CQ 34: 139-148.

Hornblower, S. (2008), A Commentary on Thucydides. Volume I: Books I-III, Oxford - New York.

Houaiss, A. (2001), Dicionário Houaiss da lingua portuguesa, Rio de Janeiro.

Howgego, Chr, Heuchert, V. Burnett, A. (eds.) (2004), Coinage and identity in the Roman provinces, Oxford.

Howgego, Chr. (2004), "Coinage and identity in the Roman provinces", in Chr. Howgego, A. Heuchert y Burnett (eds.), Coinage and identity in the Roman provinces, Oxford, 1-18.

Huizinga, J. (1948), Le déclin du Moyen Âge, Paris.

Hunter, R., Fuhrer, T. (2002), "Imaginary Gods? Poetic Theology in the Hymns of Callimachus", in F. Montanari, L. Lehnus (eds.), Callimaque. Sept Exposés suivis de discussions, Vandoeuvros-Gender, 143-175.

Hurlet, F. (1996), Les collègues du prince au temps d'Auguste et de Tibére: de la légalité républicaine à la légitimité dynastique, Roma.

Hutchinson, G. O. (1988), Hellenistic Poetry, Oxford.

HCT = Gomme, A. J., (1970), A Historical Commentary on Thucydides. vs. 1-2, Oxford. 
Icks, M. (2001), "Priestohood and Imperial Power. The Religious Reforms of Heliogabalus 220-222", in L. de Blois (ed.), Administration, Prosopography and Appointment Policies in the Roman Empire. Proceedings of the First Workshop of the International Network Impact of Empire (Roman Empire, 27 B.C. - A.D. 406), Amsterdam, 169-178.

$I R T=$ Reynolds , J. M., Ward-Perkins, J. B. (1952), Inscriptions of Roman Tripolitania, Rome.

Jackson. K. (1953), Language and history in Early Britain, Edinburgh.

Jacoby, F. (1923), Die Fragmente der griechischen Historiker, Part I-III, Berlin.

Jaeger, W. (s.d), Paideia, Trad. de Artur M. Parreira, São Paulo.

Janko R. (1982), Homer, Hesiod and the Hymns, Cambridge.

Jiménez, A. J. (1995), "La imagen de Teseo en las Suplicantes", in J. A. López Férez (ed.), De Homero a Libanio, Madrid, 145-161.

Johnson, L. (1960), "Natalis urbis and principium anni", TPAPhA 91: 109-120

Julia, D. (1962), "Les monuments funéraires en forme de demi-cylindre dans la province romaine de Tarragonaise", MCVI : 29-54.

Jullian, C. (1926), "Notes gallo-romaines”, Rérue des Études Anciennes 28. 2: 139-151.

Little, K. (2002), "Monasticism and Western Society: from marginality to the establishment and back", Memoirs of the American Academy in Rome 47: 83-94.

Kaimio, J. (1979), The Romans and the Greek Language, Helsinki.

Kalinowski, A. (2007), "A series of honorific statue bases for the Vedii in the market agora at Ephesos (IvE 725, 731, 3076-3078)", in M. Mayer, G. Baratta, A. Guzmán, (eds.), Acta XII Congressus internationalis epigraphiae Graecae et Latinae. Provinciae imperii Romani inscriptionibus descriptae, vol I, Barcelona, 757-762.

Kantiréa, M. (2007), Les dieux et les dieux augustes. Le culte impérial en Grèce sous le Julio-claudiens et les Flaviens, Études épigraphiques et archéologiques, Athènes.

Katz, S. H., Fleming, S. J., McGovern, P. E. (1996), The origins and ancient history of wine. Food and nutrition in history and anthropology 11, Amsterdam.

Kelso W.M. (ed.) (1990), Earth patterns. Essays in landscape archaeology, Charlottesville.

Kerkhecker, A. (1999), Callimachus' Book of "Iambi", Oxford.

Khanoussi, M. (1983), “Nouvelles sépultures d'époque romaine”, in Beschaouch A. et alii (eds.), Recherches archéologiques franco-tunisiennes à Bulla-Regia, I (CEFR 28/I), Roma, 93-106.

Kiss, Z. (1975), L'iconographie des princes julio-claudiens au temps d'Auguste et de Tibère, Varsovie. 
Kleiner, F. S. (1991), "The trophy on the bridge and the Roman triumph over nature", L'Antiquité Classique 60: 182-192.

Koch, J. (2009), Tartessian. Celtic in the South-west at the dawn of history, Aberystwyth.

Koch, J. (2009a), "A case for Tartessian as a Celtic language", Palaeohispanica 9: 339-351.

Kolb, A. (2001), "Tansport and communication in Roman state: the cursus publicus", in C. Adams and R. Laurence (eds.), Travel and Geography in the Roman Empire, Londres - Nova Iorque, 95-105.

Kolb, A. (ed.) (2010), Augustae. Machtbewusste Frauen am römischen Kaiserhof? Herrschaftsstrukturen und Herrschaftspraxis, Berlin.

Kozakai, T. (2000), L'étranger, l'identité. Essai sur l'integration culturelle, Paris.

Kramer, N., Reitz, Chr. (eds.) (2010), Tradition und Erneuerung. Mediale Strategien in der Zeit der Flavier, Berlin, New York.

Kristeller, P. O. (1961, 3a ed.), “The moral thought of Renaissance humanism”, in Chapters in Western civilization, I, New York, 289-335.

Krynen, J. (1981), Idéal du prince et pouvoir royal en France à la fin du Moyen Âge (1380-1440). Étude de la littérature politique du temps, Paris.

Kuhoff, W. (2001), Diokletian und die Epoche der Tetrarchie, Frankfurt.

Künzl, S. (1997), Die Trierer Spruchbecherkeramik. Dekorierte Schwarzfirniskeramik des 3. und 4. Jahrbunderts (Beihefte Trierer Zeitschrift 21), Trier.

Lambert, P. Y. (1994), La langue gauloise, Clamecy.

Lambrino, S. (1937), "La famille d'Apollon à Histria”, Aephem 100: 352-362.

Lambrino, S. (1952), "Les inscriptions de São Miguel de Odrinhas”, Bulletin des Études Portugaises 16: 134-176.

Lasserre, F. (1976), "Hérodote et Protagoras: le débat sur les constitutions", $M H$ 33: 65-84.

Lateiner, D. (1984), "Herodotean historiographical patterning: the constitutional debate", QS 20: 257-284.

Laurence, R. (2001), "Afterword: travel and empire", in C. Adams and R. Laurence (eds.), Travel and Geography in the Roman Empire, Londres / Nova Iorque, 167-176.

Lausberg, H. (1990, 3a ed.), Handbuch der literarischen Rhetorik. Eine Grundlegung der Literaturwissenschaft, Stuttgart.

Lawrance, J. N. H. (1990), "Humanism in the Iberian Peninsula", in A. Goodman, A. Mackay (eds.), The Impact of Humanism on Western Europe, Londres, 220-258.

Lazenby, J. F. (1993), The Defence of Greece, 490-479 B.C., Warminster. 
Leão, D. F. (2012), A Globalização no Mundo Antigo. Do Polites ao Kosmopolites, Coimbra.

Lehmann, K. (1962), "Ignorance and search in the villa of the Mysteries", JRS 52: $62-68$.

Leite de Vasconcelos, J. (1913), Religióes de Lusitania, III, Lisboa 1989.

Leite, S. (ed.) (1963), Estatutos da Universidade de Coimbra (1559), Coimbra.

Lekai, L. J. (1987), Los Cistercienses. Ideales y realidad, Barcelona.

Lemny, S. (2010), Cantemirestii. Aventura europeana a unei familii princiare din secolul al XVIII-lea (Les Cantemir: l'aventure européenne d'une famille princière au XVIIIe siècle, 2006), Iasi, Polirom.

Lesky, A. (1995), História da Literatura Grega, Lisboa.

Leveau, Ph. (1992), "Le territoire agricole d'Arles dans l'antiquité. Relecture de l'histoire économique d'une cité antique à la lumiere d'une histoire du milieu”, in M. Bernardi (cur.), Archeologia del Paesaggio, Firenze, vol. II, 597-636.

Levy, A. M. (2010), Sex Acts in Early Modern Italy: Practice, Performance, Perversion, Punishment, Farnham.

Lewis, D. M, Boardman, J., Hornblower, S., Ostwald, M (eds.) (1994), The Cambridge Ancient History, Volume 6: The Fourth Century BC, Cambridge.

Lewis, D. M. (1994), “The Athenian Tribute Quota Lists, 453-450 BC”, BSA 89: 285-301.

Lima, D. C. (1998, 3a ed.), Câmara Cascudo: um brasileiro feliz. Rio de Janeiro.

Lintott, A. (1992), Judicial reform and land reform in the Roman Republic, Cambridge.

Little K. (2002), "Monasticism and Western Society: from marginality to the establishment and back", Memoirs of the American Academy in Rome 47: 83-94.

Littman, R. J. (1974), The Greek experiment, Imperialism and social conflict 800400 B. C., Londres.

Liverani, P. (1994), "Il ciclo di ritratti del edificio absidato a Roselle", in Roselle: iconografia imperiale e glorificazione Familiare, MDAI, RA 101: 161-163.

Loeschcke, S. (1932), "Römische Denkmäler vom Weinbau an Mosel, Saar und Ruwer", TrZ 7: 42-60.

Loeschcke, S. (1933), Denkmäler vom Weinbau aus der Zeit der Römerherrschaft an Mosel, Saar und Ruwer, Trier.

López Moreda, S. (2009), Aulo Gelio, Noches Aticas, Madrid.

López Vilar, J. (1999-2000), “Consideracions sobre les cupae i altres estructures funeràries afins”, Bullettí Arcqueològic V. 21-22: 65-103. 
Lorenzo Gómez, F. (2010), Un dios entre los hombres. La adoración a los emperadores romanos en Grecia, Barcelona.

Losada Goya, J. M. (ed.) (2010), Mito y Mundo contemporáneo. La recepción de los mitos antiguos, medievales y modernos en la litetatura contemporânea, Bari.

Lucet, B. (1977), Les codifications cisterciennes de 1237 et de 1257, Paris.

Macan, R.W. (1908), Herodotus, The Seventh, Eighth, E Ninth Books, London.

Machado de Assis, J. M. (1971), "Esaú e Jacó", in Machado de Assis, Obra Completa, Rio de Janeiro, José Aguilar Editora.

Maehler, H. (1982), Die Lieder des Bakchylides I (2 vols.), Leiden.

Magioncalda, A. (1991), Lo sviluppo della titolatura imperiale da Augusto a Giustiniano attraverso le testimonianze epigrafiche, Torino.

Magueijo, C. (1970), “A Lex Metallis Dicta”, O Arqueólogo Português série 3, 4: 125-163.

Maltese, V. E.-Cortassa, G. (eds.)(2000), Roma parte del cielo. Confronto tra l'Antica e la Nuova Roma di Manuele Crisolora, Torino.

Mamede, Z. (1970), Luis da Câmara Cascudo: 50 anos de vida intelectual 1918/1968, Natal.

Manconi, D., Catalli, F. (eds.) (2005), Le immagini del potere. Il potere delle immagini. L'uso del ritratto ufficiale nel mondo romano da Cesare ai Severi, Perugia.

Mann, C. (2001), Athlet und Polis im archaischen und frübklassischen Griechenland, Göttingen.

Mantas, V. G. (2008-2009), "A rede viária romana em Portugal. Estado da questão e perspectivas futuras", Anas 21-22: 245-272.

Mantas, V. G. (2011), "Linhas fortificadas e vida quotidiana: da Muralha da China à Muralha do Atlântico", in C. Guardado da Silva (coord.), A Vida quotidiana nas Linhas de Torres Vedras, Torres Vedras, 15-56.

Mantas, V. G. (2012), As vias romanas da Lusitânia, Mérida.

Maquiavel, N. (2010, 8ª ed), O principe, Trad. de Pietro Nassetti, Martin Claret, São Paulo.

Maquiavel, N. (1980), Le Prince de Maquiavel, Traduction et commentaire de C. Roux-Lehman, Paris.

Maravall, J. A. (1972), Estado moderno y mentalidad social (siglos XV a XVII), 2 vols., Madrid.

Marco, F. (1993), "Nemedus Augustus", in I. J. Adiego, J. Siles, J. Velaza, (eds.), Studia Palaeohispanica et Indogermanica J. Untermann ab amicis Hispanicis oblata, Barcelona, 163-178. 
Marco, F. (1996), "Integración, interpretatio y resistencia religiosa en el occidente del imperio", in J. M. Blásquez, J. Alvard (ed.) La romanización en Occidente, Madrid, 217-238.

Marcos Casquero, M. A., Domínguez García, A. (2006), Aulo Gelio, Noches Áticas, vol. I, Universidad de León.

Marcy, G. (1936), Les inscriptions libyques bilingues de l'Afrique du nord, Paris.

Moreno Gallo, I. (2006),Vias romanas: ingenieria y técnica constructiva. Madrid.

Marlière, É. (2001), Le tonneau en Gaule Romaine», Gallia 58: 181-201.

Marlière, É. (2002), L'outre et le tonneau dans l'Occident romain, Montagnac.

Marques, M. A. F. (1998), "A introdução da Ordem de Cister em Portugal”, in Estudos sobre a Ordem de Cister em Portugal, Lisboa.

Marrou, H.-I. (1963), "L'Église dans la première moitié du quatrième siècle”, in L'Église de l'Antiquité tardive 303-604, Paris, 26-35.

Marrou, H.-I. (1965, 6ª ed.), Histoire de l'éducation dans l' Antiquité, Paris.

Marshall, P. K (1983), "Aulus Gellius", in L.D. Reynolds (ed.), Texts and Transmission. A Survey of the Latin Classics, Oxford.

Martínez, A. (1993), "Dos esgrafiados ibéricos sobre una estela romana de Requena (Valencia)", Saguntum 26: 247-251.

Martínez-Pinna, J. (2002), "Los arcadios", in La prebistoria mitica de Roma, Gerión. Anejos 6: 135-167.

Martini, W. (1990), Die archäischen Plastik der Griechen, Darmstadt.

Mastino, A. (1981), Le titolature di Caracalla e Geta attraverso le iscrizioni (indici), Bolonia.

Mattoso, A., (1935 2a ed.), Compêndio de história antiga, Sá da Costa, Lisboa.

Maurice, F. (1930), "The Size of the Army of Xerxes in the Invasion of Greece 480 B.C.", JHS 50: 210-35.

Mayer, M. (1980), "La plasmación lingüística de la pervivencia de los cultos prerromanos en Hispania a través de los formularios epigráficos", Revista Española de Lingüistica 10: 230-231.

Mayer, M. (1993), "El paganismo cívico de los siglos II y III en la Hispania citerior. Su reflejo en la epigrafía", in Ciudad y comunidad civica en Hispania. Siglos II y III d. C. Cité et communauté civique en Hispania, Madrid, 161-175.

Mayer, M. (1995), "El primer horizonte epigráfico en el litoral noreste de la Hispania citerior", in F. Beltrán (ed.), Roma y el nacimiento de la cultura epigráfica en Occidente, Zaragoza, 97-119.

Mayer, M. (1998), “¿Qué es un Augusteum?, Historia Antiqua 4: 63-70.

Mayer, M. (1999), “Aproximación a la religión cívica en Hispania bajo los 
flavios", Ktema 24: 341-345.

Mayer, M. (2004), "El Augusteum de Narona (Vid, Metković, Croacia) en época de los Severos", in Orbis Antiquus. Studia in honorem Ioannis Pisonis, ClujNapoca, 283-289.

Mayer, M. (2005), "Constantino el Grande: deconstrucción y construcción de un Imperio", in F. de Oliveira (coord.), Génese e Consolidação da Ideia de Europa, vol. III, O Mundo Romano, Coimbra, 203-230.

Mayer, M. (2007a), "La presenza imperiale nelle città del Picenum tra l'epoca augustea e il regno dei Severi : un primo aproccio", Studi Maceratesi 41: 27-40.

Mayer, M. (2007b), "Las dedicatorias a miembros de la domus Augusta julio-claudia y su soporte: una primera aproximación”, in G. Paci (ed.), Contributi all'epigrafia del'età augustea. Actes de la XIII' Rencontre francoitalienne sur l'épigraphie du monde romain, Tivoli, 171-199

Mayer, M. (2008), "Sila y el uso político de la epigrafía", in M. Caldelli, G. L. Gregori, S. Orlandi (eds.), Epigrafia 2006. Atti della XIVerencontre sur l'épigraphie in onore di Silvio Panciera con altri contributi di colleghi, allievi e collaboratori, Roma, 121-135.

Mayer, M. (2009), "Los honores recibidos por la familia de Marco Aurelio en la parte oriental del imperio romano: ¿̨cambio o continuidad en el culto dinástico?", in A. Martínez Fernández (ed.), Estudios de Epigrafía Griega, La Laguna, 277-294.

Mayer, M. (2010), "La presència de la dinastia antonina a Tarraco", in Studia Celtica Classica et Romana Nicolae Szabó septuagesimo dicata, Budapest, 159-167.

Mayer, M. (2015), "La epigrafia y el Augusteum de Narona", in G. Zecchini (ed.), L 'Augusteum di Narona. Atti della Giornata di Studi. Roma 31 maggio 2013, (Centro ricerche e documentazione sull' antichità clàssica, monografie, 3 7), Roma, pp. 19-41.

McCrum, M., Woodhead, A.G. (1961), Select Documents of the Principates of the Flavian Emperors Including the Year of Revolution, A.D. 68-96, Cambridge.

Mednikarova, I. (2003), "The accusative of the name of the deceased in Latin and Greek epitaphs", ZPE 143: 117-134.

Meiggs, R. (1972), The Athenian Empire, Oxford.

Melani, V., Vergari, M. (1985), Profilo di una città etrusca Roselle, Pistoia.

Melchor Gil, E. (1992), "Sistemas de financiación y medios de construcción de la red viaria hispana”, Habis, 23: 121-137.

Melchor Gil, E. (2010), "Homenajes estatutarios e integración de la mujer en la vida pública municipal de las ciudades de la Bética", in F. J. Navarro (ed.), Pluralidad e integración en el Mundo Romano, Pamplona, 221-245. 
Mellor, R. (1975), ӨEA P $\Omega$ MH the Worship of the Goddess Roma in the Greek World, Göttingen.

Mellor, R. (1981), “The Goddess Roma”, in $A N R W$ II 17. 2, Berlin, New York, 950-1030

Menegazzi, L. (1995), Il manifesto italiano (prima ed. 1974), Milano.

Merêa, P. (1929), História de Portugal, Vol. II. Coimbra.

Merêa, P. (1941), Suárez, Grácio, Hobbes, Coimbra.

Mesnard, P. (1977), Essor de la philosophie politique au XVIe Siècle, Paris.

Messerschmidt, W. (2003), Prosopopoiia: Personifikationen politischen Charakters in spätklassischer und hellenistischer Kunst, Köln.

Michelini, A. N. (1994), "Political themes in Euripides' Suppliants", AJPh 115. 2: $219-252$.

Millar, F. (1968), "Local cultures in the Roman Empire: Libyan, Punic and Latin”, JRS 58: 126-134.

Millar, F. (1993), The Roman Near East 31 BC-337 AD, London.

Millar, F. (2006), A Greek Roman Empire, Power and belief under Theodosius II 408-450, Berkeley.

Minerath, R. (1996), Histoire des Conciles, Paris.

$M L H=$ J. Untermann, J. (1975-2000), Monumenta linguarum Hispanicarum, $\mathrm{I}-\mathrm{V}$, Wiesbaden.

Moggi, M. (1976), I sinecismi interstatali greci, Pisa.

Moncada, C. (1947), Filosofia do direito e do estado, I, Coimbra.

Monfrin, J. (1964), "Humanisme et traductions au Moyen Age", in L'Humanisme médieval dans les littératures romanes du XIIe au XIVe siècle (Actes du Colloque organisé par le Centre de Philologie et de Littératures romanes de l'Université de Strasbourg), Paris.

Monteiro, N., d'Encarnação, J. (1993-1994), “A propósito de uma inscrição latina em Santiago da Guarda (Ansião)", Conimbriga 32-33: 303-311.

Moretti, G. (2007), "Patriae trepidantis imago. La personificazione di Roma nella Pharsalia fra ostentum e disseminazione allegorica", Camenae 2: 1-17

Morrison, A. D. (2007), The Narrator in Archaic Greek and Hellenistic Poetry, Cambridge.

Mosley, D. J. (1965), "The Size of Embassies in Ancient Greek Diplomacy”, ТРАРЬA: 255-266.

Mosley, D. J. (1972), "Envoys and diplomacy in Ancient Greece”, Historia 22: 1-97.

Mossé, Cl. (1970), La colonisation dans l'Antiquité, Paris, 27-99. 
Mullen, A. (2007), “Linguistic evidence for 'romanization': continuity and change in Romano-British onomastics: a study of the epigraphic record with particular reference to Bath", Britannia 38: 35-61.

Muñoz, V. (2005), "La interpretatio romana del dios prerromano Bandue", Veleia 22: $145-152$.

Munro, J.A.R. (1926), “Xerxes' Invasion of Greece”, in The Persian Empire and the West, Cambridge Ancient History, Vol. IV, Cambridge, 268-316.

Nascimento, A. A. (1990), "Poggio e o seu interesse por códices de Alcobaça", Revista da Faculdade de Letras de Lisboa 13-14: 37-40.

Nascimento, A. A. (1993), "As librarias dos príncipes de Avis", Biblos. Revista da Faculdade de Letras (Coimbra). Actas do Congreso Comemorativo do $6^{\circ}$ Centenário do Infante D. Pedro (25 a 27 de Novembro de 1992) 69: 265-287.

Nascimento, A. A. (1995), "La réception des auteurs classiques dans l'éspace cultural portugais: une questione ouvert", in C. Leonardi, B. Munk Olsen (eds.), The Classical Tradition in the Middle Ages and Renaissance, Spoleto, 47-56.

Nascimento, A. A. (1997), "Traduzir, verbo de fronteira nos contornos da Idade Média”, in C. Almeida Ribeiro, M. Madureira (eds.), O género do texto medieval, Lisboa, 113-138.

Nascimento, A. A. (1999), Cister. Os documentos primitivos. No 9.० Centenário da fundação de Cister (1999). Introdução, tradução e notas de Aires A. Nascimento, Lisboa.

Navarro Caballero, M. (2003), "Mujer de notable: representación y poder en las ciudades de la España imperial”, in S. Armani, B. Martineau-Hurlet, A. U. Stylow, (eds.), Acta antiqua Complutensia IV. Epigrafía y sociedad en Hispania durante el Alto Imperio: estructuras sociales, Alcalá de Henares, 119-127.

Nemeti, S. (1998), "Cultul lui Sucellus-Dis Pater şi al Nantosueltei-Proserpina în Dacia romană”, EphemNapoc 8: 95-121.

Neumann, G., Untermann, J. (eds.) (1980), Die Sprachen im Römischen Reich der Kaiserzeit. Beihefte der Bonner Jabrbücher 40, Bonn.

Nicosia, F. (ed.) (1990), Un decennio di ricerche a Roselle. Statue e ritratti, Firenze.

Nunes, E., Albuquerque, M. (1968), "Parecer do doutor 'Valasco di Portogallo' sobre o beneplácito régio (Florença, 1954)”, in V. Rau (ed.), Do tempo e da bistoria, Lisboa, t. 2, 97-139.

Ober, J. (1989), Mass and Elite in Democratic Athens. Rhetoric, Ideology, and the Power of the People, Princeton.

Odiot, T. (2004), "Le site du Molard à Donzère", in Brun, J.-P., Poux, M., Tchernia, A. (eds.), Le vin. Nectar des Dieux. Génies des Hommes, Gollion, 202-203. 
Oelmann, F. (1914), Die Keramik des Kastells Niederbieber, Frankfurt.

Ohly, D. (1976), Die Aegineten: die Marmorskulpturen des Tempels der Aphaia auf Aegina. (a) I. Die Ostgiebelgruppe. München. (b) II. Die Westgiebelgruppe. III. Altarplatzgrupen, Akrotere, etc, München.

Olteanu, T. (2008), "El culto a Victoria y la interpretatio indígena en el Occidente de Hispania, Gallia y el norte de Britania", BVallad 74: 197-224.

Ors, A. de (1953), Epigrafia juridica de la España romana, Madrid.

Pacaut, M. (1993), Les moines blancs. Histoire de l'Ordre de Cîteaux, Paris.

Pallottino, M. (1952), "El problema de las relaciones entre Cerdeña e Iberia en la antigüedad prerromana", Ampurias 14: 137-155.

Panciera, S. (2003), "Umano, sovraumano o divino? Le divinità augustee e l'imperatore a Roma", in L. de Blois, P. Erdkamp, O. Hekster, G. De Kleijn, S. Mols, (eds.), The Representation and Perception of Roman Imperial Power. Proceedings of the Third Workshop of the International Network Impact of Empire (Roman Empire c. 200 B.C. - A.D. 476), Amsterdam, 219-239.

Paparelli, G. (1973), Feritas, humanitas, diuinitas. L'essenza umanistica del Rinascimento, Napoli.

Parker, V. (1988), "Túpavvoc. The semantics of a political concept from Archilochus to Aristotle", Hermes 126. 2: 145-172.

Patillon, M. (ed.) (2002), Pseudo-Aelius Aristide, Arts rhétoriques, Paris.

Pekary, T. (1968), Untersuchungen zu den römischen Reichsstraßen, Bona.

Pellegrini, D. P. M. (2003), Le Grandi Storie dell'Auto, vol. 2, Alfa Romeo, 35-35.

Pelling, Ch. (2002), "Speech and action: Herodotus' Debate on the Constitutions", PCPhS 48: 123-158.

Peña Cervantes, Y. (2010), Torcularia. La producción de vino y aceite en Hispania. Catálogo de yacimientos analizados en cedé (Sèrie documenta 149), Tarragona.

Pensa, M. (1979), "Genesi e svilupo dell'arco onorario nella documentazione numismática”, Studi sull'Arco Onorario Romano, Roma, 19-27.

Peres, D. (1952), História de Portugal, II, Porto.

Pérez Martin, A. (1979), Proles Aegidiana. I. Introducción. Los Colegiales desde 1368 a 1500 , Bolonia.

Pérez Martin, A. (1999), Españoles en el Alma Mater Studiorum. Profesores hispanos en Bolonia (de fines del siglo XII a 1799), Murcia.

Pérez Ruiz, F. (1984), "El justo es feliz y el injusto desgraciado, justicia y felicidad en la República de Platon", Pensamiento 40, 159: 257-295.

Petrarca, F. (1581), Francisci Petrarchae Florentini Opera. Basileae, per Sebastianum Henricpetri. 
Petrarca, F. (1942), Epistolae familiares, in V. Rossi (ed.), Le Familiari, Firenze.

Petri, Ch. (1989), 'La politique de Constance II: un premier 'césaropapisme' ou l'imitatio Constantini?", in A. Dihle (coord.), L'église et l'empire au IV siècle, Genève, 113-178.

Pfeiffer, R. (1949-1951), Callimachus, 2 vols., Oxford.

Pflaum, H.G. (1976), Inscriptions latines de l'Algérie, t. II, vol. II, Inscriptions de la Confédération cirtéenne, de Cuicul et de la tribu des Suburbures, Alger.

Pflug, H. (1941), As auto-estradas do Reich, Berlim.

Pharr, C. et alii (2008), The Theodosian Code and Novels and the Sirmondian Constitution. Translation, commentary and bibliography, Union (NJ).

Piana, C. (1976), Nuovi documenti sull'Universitá di Bologna e sul Collegio di Spagna,I-II, Bolonia, Zaragoza.

Pick, B. (1898), Die antiken Münzen Nordgriechenlands I, 2. Die antiken Münzen von Dacien und Moesien, Berlin.

Piganiol, A. (1972, 2a ed.), L'empire chrétien, Paris.

Pina, R. de (1977), Chronica do Senhor Rey D. Affonso V, cap. CXXV "Das feiçoões custumes e virtudes do Yfante Don Pedro”, in M. L. de Almeida (Intro. e Revisão), Crónicas de Rui de Pina, Porto.

Pinheiro Futre, M. P. (2006), "Do Mito à Utopia: viagem ao mundo do imaginário grego" in Actas do V Congresso da APEC-Antiguidade Clássica e nós: Herança e Identidade Cultural, Braga, 569-581.

Pinho, S. T. (1999), "Os Príncipes de Avis e o Pré- Humanismo Português", in Raizes Greco-Latinas da Cultura Portuguesa. Actas do I Congresso da APEC, Coimbra, 99-133.

Pinto, Frei H. (1952), "Diálogo da justiça”, in Imagem da vida cristã, I, Lisboa.

Pippidi, D. M. (1971), I Greci nel Basso Danubio dall'età arcaica alla conquista romana, Mailand.

Pirling, R. (1993), "Ein Trierer Spruchbecher mit ungewöhnlicher Inschrift aus Krefeld-Gellep", Germania 71: 387-404.

Podlecki, A. J. (1976), “Athens and Aegina”, Historia 25.4: 396-413.

Poenaru Bordea, G. (1979), "Les statères ouest-pontiques de type Alexandre le Grand et Lysimaque”, RBNS 125: 37-51.

Prag, J. R. W. (2002), "Epigraphy by numbers: Latin and the epigraphic culture in Sicily", in A. E. Cooley (ed.), Becoming Roman, Writing Latin? Literacy and Epigraphy in the Roman West. JRA Suppl. Ser. 48: 15-31.

Preda, C., Popescu, E., Diaconu, P. (1962), "Săpăturile arheologice de la Mangalia (Callatis)", Materiale 8: 439-455.

Pressouyre, L. (1990), Le rêve cistercien, Paris. 
Price, S. R. F. (1984), Rituals and Power. The Roman Imperial Cult in Asia Minor, Cambridge.

Privitera, G. A. (1988), "Pindaro, Nem. III 1-5 e l'acqua di Egina”, QUCC 58: 63-70.

Puerta Torres, C. (1995), Los miliarios de la Vía de la Plata, 1-2, Madrid.

Quadrino, D. (2007), Una nuova iscrizione onoraria di Adriano e il Sebasteion di Kestros in Cilicia Tracheia, Tivoli.

Radnoti Alföldi, M., Rasbach, G. (1999), "Zur Frage der interpretatio Romana“, in Festschrift für Günter Smolla, Wiesbaden, 597-605.

Raepsaet-Charlier, M. Th. (1975), "La datation des inscriptions latines dans les provinces occidentales de l'Empire Romain d'après les formules " In $\mathrm{H}$ (onorem) D(omus) D(ivinae) » et «Deo, Deae »", in ANRW II 3: 232-282.

Raepsaet-Charlier, M. Th. (2005), "Les sacerdoces des femmes sénatoriales sous le Haut-Empire", in M.-F. Baslez, F. Prévot (eds.), Prosopographie et histoire religieuse. Actes du colloque tenu en l'Université Paris XII-Val de Marne le 27 E 28 octobre 2000, Paris, 283-304.

Ramalho, A. C. (1985), Latim Renascentista em Portugal (Antologia), Coimbra.

Rapp, Cl. (2005), Holy Bishops in Late Antiquity, The nature of Christian Leadership in an age of transition, Berkeley.

Rau, V. (1969), "Italianismo na cultura jurídica portuguesa do século XV", Revista Portuguesa de História 12.1: 185-206.

Rau, V. (1973), "Studenti ed eruditi portoghesi in Italia nel secolo XV", Estudos Italianos em Portugal 36: 7-73.

Rawlinson, H. G. (1916), Intercourse between India and the Western World from the Earliest Times to the Fall of Rome, Cambridge.

Rebelo, D. L. (1951), Do governo da republica pelo rei (de republica gubernanda per regem), reprodução fac-similada da edição de 1496, Introdução e notas de A. M. de Sá, Lisboa.

Rebelo, L. de S. (1983), A concep̧̣ão do poder em Fernão Lopes, Lisboa.

Rebuffat, R. (2007), "Pour un corpus des bilingues punico-libyques et latinolibyques", in M. H. Fantar (ed.), Osmose etnho-culturelle en Méditerranée, Tunis, 183-242.

Regra do Patriarca S. Bento (1992), Edições “Ora \& Labora”, Singeverga.

Rhodes, P. J. (1993), A Commentary on the Aristotelian ATHENAION POLITEIA, Oxford.

Rhodes, P. J. (2006), A History of the Classical Greek World 478-323 BC, Molden. RIB = Collingwood, R. G. (1965), The Roman inscriptions of Britain. I. Inscriptions on stone, Oxford. 
RIG = P.-M. Duval (ed.), Recueil des inscriptions gauloises, Paris 1985-. I: M. Lejeune, Textes gallo-grecs, 1985; II.1: M. Lejeune, Textes gallo-étrusques. Textes gallo-latins sur pierre, 1988; II.2: P.-Y. Lambert, Textes gallo-latins sur instrumentum, 2002; III: P.-M. Duval y G. Pinault, Les calendriers (Coligny, Villards d'Héria), 1988; IV: J.-B. Colbert de Beaulieu y B. Fischer, Les légendes monétaires, 1998.

Ripollés, P. P. (2004), "Coinage and identity in the Roman provinces: Spain", in Ch. Howgego, V. Heuchert, A. Burnett (eds.), Coinage and identity in the Roman provinces, Oxford, 79-93.

Ripollés, P. P., Velaza, J. (2002), "Saguntum, colonia latina”, ZPE 141: 285-294.

Rodgers, B. (1989), “The Metamorphosis of Constantine”, CQ 39.1: 233-246.

Rodrigues, M. A. (1993), "O infante D. Pedro e a Universidade”, Biblos. Revista de Faculdade de Letras (Coimbra). Actas do Congreso Comemorativo do $6^{\circ}$ Centenario do Infante D. Pedro (25 a 7 de Novembro de 1992) 69: 345362.

Rodrigues, N. S. (2007), "Entre Europa e Io: elementos orientais na arte grega arcaica e clássica", in J. A. Ramos, L. M. Araújo, A. Ramos dos Santos (eds.), Arte Pré-Clássica. Colóquio Comemorativo dos Vinte Anos do Instituto Oriental da Faculdade de Letras da Universidade de Lisboa, Lisboa, 323346.

Rodríguez, P., Díez de Pinos, E. (2014), "Nueva inscripción celtibérica en piedra de E1 Pueyo de Belchite (Zaragoza)", Palaeohispanica 14: 245-262.

Rodríguez Colmenero, A., Ferrer Sierra, S., Álvarez Asorey, R. (2004), Miliários e outras inscricións viarias romanas do noroeste hispánico. Santiago de Compostela.

Rocha Pereira, M. H. (1981), "O mais antigo texto europeu de teoria política", Nova Renascença 1: 364-370.

Rocha Pereira, M. H. (1990), “O 'Diálogo dos Persas’ em Heródoto”, Estudos Portugueses. Homenagem a António José Saraiva, Lisboa, 351-362.

Rocha Pereira, M. H. (2003), Hélade. Antologia da Cultura Grega, Asa, Porto.

Rocha Pereira, M. H. (2008, 8a ed.), Sófocles: Antígona, Coimbra.

Roha Pereira, M. H. (2009, 10ª ed.), Hélade, Lisboa, Guimarães.

Rocha Pereira, M. H. (2012), Estudos de História da Cultura Clássica, vol.1 Cultura Grega, Lisboa.

Roldán Hervás, J. (1975), Itineraria Hispana. Fuentes antiguas para el estudio de las vías romanas en la Peninsula Ibérica, Madrid.

Röllig, W. (1980), “Das Punische im Römischen Reich”, in G. Neumann, J. Untermann (eds.), Die Sprachen im Römischen Reich der Kaiserzeit. (Bonner Jabrbücher des Rheinischen Landesmuseums in Bonn im Landschaftsverband 
Bibliografia

Rheinland und des Vereins von Altertumsfreunden im Rheinlande 40), Köln, 285-299.

Romano, E. (2006-2009), "Le tombe "a cupa" in Italia e nel Mediterraneo. Tipologia architettonica, committenza e rituale”, StClOr 52: 149-219.

Romilly, J. de (1959), "Le classement des constitutions d'Hérodote à Aristote", REG 72: 81-99.

Rose, C. B. (1997), Dynastic Commemoration and Imperial Portraiture in the Julio-Claudian Period, Cambridge.

Rosenthal, F. (1936), Die Sprache der palmyrenischen Inschriften und ibre Stellung innerhalb des Aramäischen, Leipzig.

Rosivach, V. J. (1977), "Earthborns and Olympians: the parodos of the Ion", CQ 27. 2: 284-294.

Rosivach, V. J. (1988), "The Tyrant in Athenian Democracy", QUCC 59: 43-57.

Rossillon, Ph. (ed.) (1995), Atlas de la langue française, Paris.

Rossiter, J. J. (1978), Roman Farm Buildings in Italy (BAR int. Ser. 52), Oxford.

Rössler, O. (1980), "Libyen von der Cyrenaica bis zur Mauretania Tingitana", in G. Neumann, J. Untermann (eds.), Die Sprachen im Römischen Reich der Kaiserzeit. (Bonner Jabrbücher des Rheinischen Landesmuseums in Bonn im Landschaftsverband Rheinland und des Vereins von Altertumsfreunden im Rheinlande 40). Köln, 267-284.

Rubenstein, L. (2004), "Ionia", in M. H Hansen, T. H. Nielsen (eds.), An Inventory of Archaic and Classical poleis, Oxford, 1053-1107.

Rucquoi, A. (2003), "Rois et princes portugais chez les auteurs castillans du $\mathrm{XV}^{\mathrm{e} m e}$ siécle», Península. Revista de Estudos Ibéricos. Entre Portugal e Espanha. Relaçôes Culturais (sécolos XV-XVIII). In Honorem Jose Adriano de Freitas Carvalho, 0: 39-51.

Ruggini, L. C. (1989), "Felix Temporum Reparatio", in A. Dihle (coord.), Realtà socio-economiche in movimento durante un ventennio di regno (Costanzo II Augusto, 337-361 d.C.), L'église et l'empire au IV siècle, Genève, 179-243.

Rüpke, J. (2005), Fasti sacerdotum. Die Mitglieder der Priesterchaften und das sakrale Funktionspersonal römischer, griechischer, orientalischer und jüdischchristlicher Kulte in der Stadt Rom von 300 v. Chr. bis 499 n. Chr., Wiesbaden.

Rusjaeva, A., Vinogradov, Ju. G., (2000), "Apollon Ietros. Herrscher von Istros”, in A. Avram, M. Babeş (eds.), Olbia, Civilisation grecque et cultures antiques périphériques. Hommages à P. Alexandrescu à son $70^{\circ}$ anniversaire, Bucarest, 229-234.

Rutishauer, B. (2012), Athens and the Cyclades. Economic Strategies 540-314 BC, Oxford. Sabbadini, R. (1905), Le scoperte dei codici latini e greci ne' secoli XIV e XV , Florencia. 
Sabbadini, R. (1914), Le scoperte dei codici latini e greci ne' secoli XIV e XV, Florencia.

Saddington, D.B. (1999), "Roman soldiers, local gods and interpretatio Romana in Roman Germany", ActaCl 42:155-169.

Salazar, A. M. (1976), "El impacto humanístico de las misiones diplomáticas de Alonso de Cartagena en la Corte de Portugal entre medievo y renacimiento (1421-31)", in A. D. Deyermond (ed.), Medieval Hispanic Studies presented to Rita Hamilton, Londres, 215-226.

Salinas, M. (1995), "Los inicios de la epigrafía en Lusitania oriental", in F. Beltrán (ed.), Roma y el naámiento de la cultura epigráfica en Occidente, Zaragoça, 281-291.

Salway, B. (2001), "Travel, Itineraria and Tabellaria", in C. Adams and R. Laurence (eds.), Travel and Geography in the Roman Empire, Londres, Nova Iorque, 22-66.

Santo Agostinho (2009 12a ed. ), A cidade de Deus, trad. de Oscar Paes Leme, 2 v., Vozes, Petrópolis, São Paulo.

Santos, M. J. A. (1998), Vida e morte de um mosteiro cisterciense. S. Paulo de Almaziva - Séculos XIII-XV, Lisboa.

Saumagne, C. (1928), "Iter populo debetur", Révue d'Histoire, de Littérature et d'Histoire Anciennes 54: 320-353.

Scheer, T. S. (2003), "The Past in na Hellenistic Present: Myth and Local Tradition", in A. Erskine (ed.), A Companion to the Hellenistic World, Oxford, 216-231.

Scheid, J. (2015), "Les Augustea et le culte des empereurs. Réflexions sur les rites célébrés dans ces lieux de culte", in P. Gros, E. Marin, M. Zink (eds.), Auguste, son époque et l 'Augusteum de Narona. Actes du colloque organisé à l'Académie des Inscriptions et Belles-Letres et l'Université Catholique de Croatie (Zagreb) 12 décembre 2014, 17-30, Paris.

Schilardi, G. (ed.) (1997), Filostrato. Immagini, Lecce.

Schmidt, R. (1980), "Die Ostgrenze von Armenien über Mesopotamien, Syrien bis Arabien”, in G. Neumann, J. Untermann (eds.), Die Sprachen im Römischen Reich der Kaiserzeit. (Bonner Jahrbücher des Rheinischen Landesmuseums in Bonn im Landschaftsverband Rheinland und des Vereins von Altertumsfreunden im Rheinlande 40). Köln, 187-214.

Schmidt, Th., Fleury, P. (2011), Perceptions of the Second Sophistic and its Times. Regards sur la seconde sophistique et son époque, Toronto, Buffalo, London.

Schwartz, J. (1960), Pseudo-Hesiodeia: recherches sur la composition, la diffusion et la disparition ancienne d'oeuvres attribuées à Hésiode, Leiden.

Scott, K. (1936), The Imperial Cult under the Flavians, Stuttgart.

Sealey, R. (1976), A bistory of Greek city-states 700 -338 B. C. Berkeley. 
Seignobos, Ch. (1969), Histoire sincère de la nation française, Paris.

Semerari, L. (2000), Aula Magna Università degli Studi di Bari, Bari.

Sergent, B. (2006), "Sucellus et le tonneau", in Anthropology of the Indo-European World and Material Culture. Proceedings of the 5th International Colloquium of Anthropology of the Indo-European World and Comparative Mythology, Budapest, 61-80.

Serra, J. C. da (1972), Academia Real das Sciencias de Lisboa, II, cap. VII, Lisboa. Sforza, W. C. (1951), “Osservazioni sul 'De nobilitate legum' di Coluccio Salutati”, in E. Castelli (ed.), Umanesimo e Scienza politica (Atti del congresso Internazionale di Studi Umanistici, Roma-Firenze, 1949), Milano.

Shapiro, H.A. (1993), Personification in Greek art: the representation of abstract concepts 600-400 b.C., Zürich.

Shaw, M. H. (1982), “The $\tilde{\eta} \theta$ os of Theseus in 'The Suppliant Women”, Hermes 110. 1: 3-19.

Shorrock, R. (2011), The Myth of Paganism: Nonnus, Dionysus and the World of Late Antiquity, Bristol.

Sigeia, L. (1970), Dialogue de deux jeunes filles sur la vie de retraite (1552), Présenté, traduit et annoté par O. Sauvage (ed.), Paris.

Sillières, P. (1990), Les voies de communication de l'Hispanie méridionale, Paris.

Silva, N. J. E. G. (1964), Humanismo e Direito em Portugal no século XVI, Lisboa.

Simón, I. (2013), Los soportes de la epigrafía paleohispánica. Inscripciones sobre piedra, bronce y cerámica, Zaragoza, Sevilla.

Siniscalco, P. (2004, 5a ed.), Il cammino di Cristo nell'Impero romano, Roma, Bari.

Slavazzi, F. (2006), "Il ciclo di relievi della Kaisersaal del ginnasio di Vedio a Efeso", in Iconografía 2005. Immagini e immaginari dell'antichità classica al mondo moderno, Roma, 235-243

Smyth, A. C. (2011), Polis and Personification in Classical Athenian Art, Leiden.

Snodgrass, A. M. (1977), Archaeology and the rise of the Greek state, Cambridge.

Snodgrass, A. M. (1980), Archaic Greece. The age of experiment, Londres.

Soares, C. (2008), Platão. O Político. Tradução do grego, introdução e notas, Lisboa.

Soares, C. (2014), “Theoria e práxis política em Heródoto”, Cuadernos de Filología Clássica: Estudios griegos e indoeuropeus 24: 57-79.

Soares, N. C. (1994), O príncipe ideal no século XVI e a obra de D. Jerónimo Osório, Coimbra.

Soares, N. C. (2002), "O infante D. Pedro e a cultura portuguesa", Biblos. Revista da Faculdade de Letras 78:107-128. 
Sodano, A. R. (1970), Porphyrii Quaestionum Homericarum Liber I, Napoli.

Solas, J. G. (2008), “Escrito sobre la ciudad”, Pensar la publicidad, II, n. 2: 37-62.

Sordi, M. (1965), Il cristianesino e Roma, Bologna.

Sordi, M. (1984), I cristiani e l'impero romano, Milano.

Soria, A. (1956), Los humanistas de la Corte de Alfonso el Magnánimo (según los epistolarios), Granada.

Sousa, D. A. C. de (1946-1954), Memória dos livros do uso del Rey D. Duarte, in Provas da história genealógica da casa real portuguesa, tomo I, liv. III, Coimbra.

Sousa, R., Fialho, M. C., Haggag, M., Rodrigues, N. S. (2013), Alexandrea ad Aegyptum: The Legacy of Multiculturalism in Antiquity, Lisboa.

Spickermann, W. (1997), "Aspekte einer neuen regionalen Religion und der Prozess der "interpretatio" im römischen Germanien, Rätien und Noricum", in Römische Reichsreligion und Provinzialreligion, Tübingen, 145-167.

Spyridakis, S. (1968), “Zeus is Dead: Euhemerus and Crete”, CJ 63: 337-340.

Stafford, E., Herrin, J. (eds.) (2005), Personification in the Greek World from Antiquity to Byzantium, Burlington.

Statuta capitulorum generalium ordinis Cisterciensis ab anno 1116 ad annum 1786 edidit Josephus M. ${ }^{\text {ia } C a n i v e z ~(1933-1941), ~} 8$ vols., Louvain.

Stefan, A. (2005), "Le titre de filius Augustorum de Maximin et Constantin et la théologie de la tétrarchie", in M.-F. Baslez, F. Prévot (eds.), Prosopographie et histoire religieuse. Actes du colloque tenu en l'Université Paris XII-Val de Marne le 27 Eं 28 octobre 2000, Paris, 329-349

Stefani, G. (1986), "I cippi a botte della provincia Sardinia”, Nuovo bullettino Archeologico Sardo 3: 115-160.

Stefani, G. (1988), "Cippi a botte nella basilica di S. Saturnino a Cagliari”, Quaderni della Soprintendenza archeologica per le province di Cagliari e Oristano 5: 167-175.

Stegmann, A. (1977), "La place de la praxis dans la notion de 'raison d'État' ", in Théorie et pratique politiques à la Renaissance, Paris.

Steinbrecher, M. (1985), Der Delisch-Attischen Seebund und die AthenischSpartanischen Beziehungen in der Kimonischen Ära (478/77-462/1), Berlin.

Stemmer, K (ed.) (1995), Standorte - Kontext und Funktion antiker Skulptur, Berlin.

Sterckx, C. (2008), "Sucellos et le casque d'Hadès", in Philomythia. Mélanges offerts à Alain Moreau, Monts, 223-229.

Stern, J. (1996), Palaephatus. Peri Apiston: On Unbelievable Tales, Wauconda. 
Stern, J. (1999), "Rationalizing Myth: Methods and Motives in Palaephatus" in R. Buxton, R. (ed.), From Myth to Reason? Studies in the Development of Greek Thought, Oxford, 215-222.

Stewart, A. (1990), Greek Sculpture: an exploration, New Haven, Yale.

Storey, I. C. (2003), Eupolis poet of old comedy, Oxford.

Stowe Mead, G. R. (1901), Apollonius of Tyana, the Philosopher-Reformer of the First Century A.D., London.

Strassler, R. B. (ed.) (2007), Landmark Herodotus: The Histories, New York.

Strassler, R.B. (ed.) (2009), Landmark Herodotus: The Histories, New York.

Strootman, R. (2010), "Literature and the Kings", in Clauss, J., Cuypers, M. (eds.), A Companion to Hellenistic Literature, Malden, Oxford, 30-45.

Suberbiola Martínez, J. (1987), Nuevos concilios hispano-romanos de los siglos III y IV. La colección de Elvira, Málaga.

Szabó, Á. (2007), Daciai papság, Budapest.

Szabó, Á. (2008), "Sulla questione dello statuto giuridico dei sacerdoti provinciali durante il principato. Studio preliminare”, Iustum Aequum Salutare 4: 71-81.

Tamerl, I. (2008), Das Holzfass in der römischen Antike mit einer Studie zu Fassfunden in Raetien, Diplomarbeit presso l'Università di Innsbruck, consultabile presso la Universitäts- und Landesbibliothek Innsbruck DG43696.

Tate, J. (1927), “The Beginnings of Greek Allegory”, CR 41.6: 214-215.

Tchernia, A. (1986), Le vin de l'Italie romaine. Essai d'bistoire économique d'après les amphores (BEFAR 261), Rome.

Teive, D. de (1786), Epodos Que Cont'em Sentenças Uteis A todos os Homens, A's quaes se acrescentão Regras para a boa educação de hum principe. Trad. no vulgar em verso solto por Francisco de Andrade (conforme à ed. de Lisboa, 1565), Lisboa, Na Of. Patr. de Francisco Luiz Ameno.

Temporini, H. (1978), Die Frauen am Hofe Trajans. Ein Beitrag zur Stellung der Augustae im Principat, Berlin, New York.

Thomson de Grummond, N. (2006), Etruscan Myth. Sacred History, and Legend, Philadelphia.

Tomlin, R. S. O. (1987), "Was ancient British Celtic ever a written language? Two texts from Roman Bath", Bulletin of the Board of Celtic Studies 34: 18-25.

Topál,J. (1990), “Der Import der sogenannten Moselweinkeramik in Pannonien”, ReiCretActa 27-28: 177-184.

Tortorici, E. (1975), Castra Albana. Forma Italia, Regio I, Roma.

Touchard, J. (1959), Histoire des idées politiques, I. Paris [trad. port. Lisboa, 1970]. 
Tranoy, A. (1981), La Galice romaine, Paris.

Tuchelt, K. (1981), "Zum Problem Kaisareion-Sebasteion. Eine Frage zu den Anfängen des römischen Kaiserkultes”, MDAI, 31 : 167-186.

Ulbert, G. (1959), "Römische Holzfässer aus Regensburg”, Bayerische Vorgeschichtsblätter 24: 6-29.

Ullman, B. L. (1963), The humanism of Coluccio Salutati, Padova.

Ullmann, W. (1980), Radici del Rinascimento (tr. ital.), Roma, Bari.

Unz, R.K. (1985), "The Surplus of the Athenian phoros", GRBS 26: 21-42.

Ureña Prieto, M. H. (2001), Dicionário de Literatura Grega, Lisboa.

Valiño, A. (1999), "La cerveza en las fuentes romanas. Base textual y fijación de su importancia”, AncHistB 13: 60-71.

Van Haeperen, F. (2002), "Le collège pontifical (3ème s. a.C.-4ème s. p.C.)", Études de Philologie, d'Archéologie et d'Histoire Anciennes 39: 11-42.

Varner, E.R. (2004), Mutilation and transformation. Damnatio memoriae and Roman Imperial Portraiture, Leiden, Boston.

Várzeas, M. I. O. (2013), "Callimachus and the New Paths of Myth”, in R. Sousa et alii (coord.) Alexandrea ad Aegyptom: the legacy of multiculturalismo in antiquity. Lisboa.

Velaza, J. (2003), "Epigrafía ibérica emporitana: bases para una reconsideración”, Palaeohispanica 3: 179-192.

Velaza, J. (2003a), "Las inscripciones monetales”, in P. P. Ripollés, M. del M. Llorens, Arse-Saguntum. Historia monetaria de la ciudad y su territorio, Sagunto, 121-148.

Velaza, J. (2009), “Epigrafía y literacy paleohispánica en territorio vascón”, Palaeohispanica 9: 611-622.

Vergerio, P. P. (1934), “Epistolario di Pier Paolo Vergerio”, in L. Smith (ed.), Fonti per la storia d'Italia, vol. 74, Roma, 436-445.

Vierneisel, K., Zanker, P. (1979), Die Bildnisse des Augustus: Herrscherbild und Politik in kaiserlichen Rom, München.

Villar, F., Pedrero, R. (2001), “Arroyo de la Luz III”, Palaeohispanica 1: 235274.

Vinogradov, J. G. (2000), "Heilkundige Eleaten in den Schwarzmeergründungen”, in M. Dreher (ed.), Bürgersinn und staatliche Macht. Festschrift für Wolfgang Schuller zum 65. Geburtstag, Konstanz, 133-149.

Vittinghoff, F. (1951), Römische Kolonisation und Bürgerrechtspolitik unter Caesar und Augustus, Wiesbaden.

Vives, J., Marín, T., Martínez, G. (1963), Concilios visigóticos e hispano-romanos, Madrid, Barcelona. 
Voragine, T. (2004), Legenda Aurea. Apresentação do Cardeal Dom José Saraiva Martins e introdução do Doutor Aníbal Pinto de Castro. Tomo Segundo, Porto.

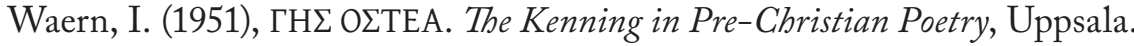

Wallace, M. B., Figueira, T. J. (2010), "Notes on the Island Phoros", ZPE 172: 65-69.

Wallace-Hadrill, A. (2005), "Mutatas formas: The Augustan Transformation of Roman Knowledge", in K. Galinsky (ed.), The Cambridge Companion to the Age of Augustus, Cambridge, 55-84.

Wallinga, H. T. (2005), Xerxes' Greek Adventure. The Naval Perspective, Leiden.

Walter, H. (1993), Ägina: die archäologische Geschichte einer griechischen Insel, München.

Walters, K. R. (1981), "Four Hundred Athenian Ships at Salamis?”, RbM 124: 199-203.

Wankel, H. (1983), "Thukydides 1,74,1 und die Schiffszahlen von Salamis," ZPE 52: 63-66.

Wells, J. (1923), Studies in Herodotus, Oxford.

Wesseling, P. (ed.) (1735), “Itinerarium Antonini Augusti”, Vetera Romanorum Itineraria, Amesterdão.

West, M. L. (1985), The Hesiodic Catalogue of Women: Its Nature, Structure, and Origins, Oxford.

Westrem, S. D. (2001), The Hereford Map. A Transcription and Translation of the Legend with Commentary, Turnhout.

Williams, D. (1987), "Aegina, Aphaia-Tempel XI: the pottery from the second limestone temple and the later history of the sanctuary", $A A$ : 629-680.

Williamson, G. (2004), "Aspects of identity", in C. Howgego, V. Heuchert, A. Burnett (eds.), Coinage and Identity in the Roman Provinces, Oxford, 19-27.

Winiarczyk, M. (2013), The «Sacred History» of Eubemerus of Messene, Berlin.

Witschel, Chr. (1995a), "Römische Tempelkultbilder und Römische Kaiserstatuen als Tempelkultbilder", in K. Stemmer, (ed.), Standorte. Kontext und Funktion antiker Skulptur; Ausstellungskatalog Abgußsammlung, Berlin, 250-265.

Witschel, Chr. (1995b), "Statuen auf römischen Platzanlagen unter besonderer Berücksichtigung von Timgad (Algerien)", in K. Stemmer (ed.), Standorte. Kontext und Funktion antiker Skulptur; Ausstellungskatalog Abgußsammlung, Berlin, 332-358.

Witschel, Chr. (2002), "Zum Problem der Identifizierung von munizipalen Kaiserkultstätten”, Klio 84: 114-124. 
Wlosok, A. (ed.) (1978), Römischer Kaiserkult, Darmstadt.

Wojciechowski, P. (2002), "Il culto di Beleno ad Aquileia romana. Origini, interpretatio Romana e la cosiddetta rinascita celtica", in Gli echi della terra. Presenze celtiche in Friuli. Dati materiali e momenti dell' immaginario. Convegno di studi, Castello di Gorizia, 5 - 7 ottobre 2001, Pisa, 29-35.

Woodard, R. (ed.) (2007), The Cambridge Companion to Greek Mythology, Cambridge.

Woodhead, A. G. (1962), The Greeks in the West. London. (Trad. port., Os Gregos no Ocidente).

Woolf, G. (1996), "Monumental writing and the expansion of the Roman society in the Early Empire", JRS 86: 22-39.

Woolf, G. (2002), "Afterword. How the Latin West was won”, in A. Cookey (ed.), Becoming Roman, writing Latin? Literacy and Epigraphy in the Roman West, JRA Suppl. Ser. 48: 181-188.

Yatromanolakis, Y. (2005), "Poleos erastes. The Greek city as the beloved", in E. Stafford, J. Herrin (eds.), Personification in the Greek World: From Antiquity to Byzantium, London, 267-284.

Young, T. Cuyler (1980), “480/479 B.C. - A Persian Perspective”, Iranica Antiqua 15: 213-39.

Zamora, J. A. (2005), "La práctica de escribir entre los primeros fenicios peninsulares y la introducción de la escritura entre los pueblos paleohispánicos”, Palaeohispanica 5: 155-19.

Zanichelli, G. Z. (2005), "Il mito di Troia nell'immaginario medievale”, in G. Burzacchini (coord.), Troia tra realtà e leggenda, Parma.

Zanker, P. (1983), Provinzielle Kaiserporträts. Zur Rezeption der Selbstdarstellung der Princeps, München.

Zaoli, G. (1912), “Lo Studio bolognese e papa Martino V”, Studi e Memorie per la storia dell'Università di Bologna I - série v. III: 105-188.

Zecchini, G. (ed.) (2015), L'Augusteum di Narona. Atti della Giornata di Studi. Roma 31 maggio 2013, (Centro ricerche e documentazione sull'antichità clàssica, monografie, 37), Roma.

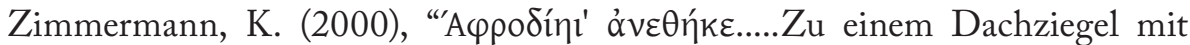
Votivinschrift", in A. Avram, M. Babeş (eds), Olbia, Civilisation grecque et cultures antiques périphériques. Hommages à $P$. Alexandrescu à son $70^{\circ}$ anniversaire, Bucarest, 239-251.

Zurara, G. E. de (1972), Chronica do Conde Dom Pedro de Meneses, II, Lisboa. 